\title{
Contents
}

List of Illustrations $\quad$ ix

Acknowledgements $\quad$ xi

Introduction: Situated Histories of the Female Self 1

1 Feminist Genealogies in the Writing of the Self

Tracing genealogies $\quad 7$

Dangerous liaisons: genealogies and critical feminisms 22

Histories of the self: the autobiographical encounter 29

Mapping the genealogical domain 37

2 Spacing the Female Self: Tracing Heterotopias 52

On spaces, places and genders $\quad 54$

A room of one's own $\quad 62$

Travellers $\quad 67$

$\begin{array}{ll}\text { Of other spaces } & 75\end{array}$

3 Erasing Sexuality from the Blackboard?

Recovering the Silence of Bodies 103

Women teachers: 'the other Victorians' 105

Passions $\quad 122$

Rewriting the script: technologies of the female self $\quad 129$

4 What is Our Present Today?

Genealogies as Histories of the Present 134

The female self in education: reversing the discourses 136

Juggling with time restrictions 141

Going out, going up, going beyond 148 
viii Contents

5 Technologies of the Female Self 154

Living in transition: know thyself/know yourselves 158

Beyond dilemmas and fears: letter-writing as a technology of the self

In way of revision: ethics and aesthetics in the care of the self

Notes

Bibliography

184

Index of Names

195

Index of Subjects

197 


\section{1 \\ Feminist Genealogies in the Writing of the Self}

Whenever I have tried to carry out a piece of theoretical work it has been on the basis of my own experience, always in relation to processes that I saw taking place around me. It is because I thought I could recognize in the things I saw, in the institutions with which I dealt, in my relations with others, cracks, silent shocks, malfunctionings...that I undertook a particular piece of work, a few fragments of autobiography. (Foucault, 1988d, p. 156)

To assert that the social representation of gender affects its subjective construction and that vice versa, the subjective representation of gender - or self-representation - affects its social construction, leaves open a possibility of agency and self-determination at the subjective and even individual level of micropolitical and everyday practices. (de Lauretis, 1987, p. 9)

Autobiography provides a stage where women writers, born again in the act of writing, may experiment with reconstructing the various discourses - of representation, of ideology - in which their subjectivity has been formed. Thus the subject of autobiography is not a single entity but a network of differences within which the subject is inscribed. The subject is already multiple, heterogeneous, even conflicted, and these contradictions expose the technologies of autobiography. (Gilmore, 1994, p. 85)

In 1966, Foucault surprised everybody by suggesting that man did not exist before the end of the eighteenth century, that [he] was 'a recent creature [...] fabricated with its own hands' (1970, p. 308) and that it was quite possible that [he] could again 'be erased, like a face drawn in sand at the edge of the sea' (1970, p. 384). Two years later, Roland 
Barthes would announce 'the death of the author' as a source of meaning behind the text. If we were then facing the disappearance of man and the death of the author, would this mean that 'we were also witnessing the death of autobiography?' Linda Anderson has eloquently asked (2001, p. 14).

At the same time that these terrible deaths and disappearances were being announced, Foucault was writing lovely narratives, some of them perhaps too good or too bad to be true. Foucault was an exceptional storyteller. Anybody could disagree with what he was suggesting, but nobody could deny that his narratives have always been seducing and compelling. It is well known that his books soon moved beyond academic circles and reached a wider audience. Moreover many of the stories Foucault wrote were partly autobiographical, as the above quote indicates.

This chapter is therefore concerned with the encounter of Foucauldian genealogies, critical feminisms, and autobiographical writings. In the context of this discursive analytical triangle I will consider [man's] disappearance as an immensely thrilling and exciting theme that has been radically reworked in the narratives revolving around the construction of female subjectivities. These autobiographical narratives, I will argue, have constructed a space 'in the margins of hegemonic discourses' (de Lauretis, 1987, p. 18) for the female self in education to emerge rather than disappear. This emergence, however, has not constituted a unitary core self, but rather a matrix of subject positions for women 'writing themselves' to inhabit, not in a permanent way, but rather temporarily, as points of departure for going elsewhere, becoming other. As Teresa de Lauretis has argued, '[being] inscribed in micropolitical practices, the terms of a different construction of gender exist, [...] and their effects are rather at the "local" level of resistance, in subjectivity and selfrepresentation' (de Lauretis, 1987, p. 18).

But let us look more closely at the analytical triangle, particularly focusing on each of its three theoretical planes, namely Foucauldian genealogies, critical feminisms, autobiographical writings and let us start raising a series of questions; first of all: what is genealogy?

\section{Tracing genealogies}

As already pointed out, Foucault has written lovely histories. Although tempting, however, Foucauldian histories are far from being recognized as valid or indisputable. Foucault himself has written: 
I am well aware that I have never written anything but fictions. I do not mean to say, however, that truth is therefore absent. It seems to me that the possibility exists for fiction to function in truth, for a fictional discourse to induce effects of truth, and for bringing it about that a true discourse engenders or 'manufactures' something that does not as yet exist, that is, 'fictions' it. One 'fictions' history on the basis of a political reality that makes it true, one 'fictions' a politics not yet in existence on the basis of a historical truth. (Foucault, 1980c, p. 193)

Against what are seen as traditional types of history, Foucault has proposed the Nietzschean theme of genealogy. This is what he calls the form of his reflection on the nature and development of modern power. A key Nietzschean insight for Foucault is that truth cannot be separated from the procedures of its production. The philosopher's task is therefore to criticize, diagnose and demythologize 'truth phenomena'. Consequently genealogy is concerned with the processes, procedures and apparatuses, whereby truth and knowledge are produced, in what Foucault calls the discursive regime of the modern era. Instead of asking in which kinds of discourse we are entitled to believe, Foucault's genealogies pose the question of which kinds of practices, linked to which kinds of external conditions, determine the different knowledges in which we ourselves figure.

Drawing on the Enlightenment suggestion of 'emancipation from selfimposed immaturity' (Rajchman, 1985, p. 56), the Foucauldian genealogy writes the history of the present. It starts asking Kantian questions: 'What is my present? What is the meaning of this present? And what am I doing when I speak of this present' (Foucault, 1988b, p. 89).

According to Foucault, these questions of the 'Auflarung,' or of reason, have been a central theme of philosophy from Kant to our own day. Like Kant, Foucault sees the present as a process that embodies thought, knowledge and philosophy. In reframing the Kantian questions, however, Foucault follows different trails to explore them.

In examining the very Kantian concept of the present, Foucault introduces scepticism about universalistic dogmas of truth, objectivity and pure scientific reason, and interrogates the supposed interconnections between reason, knowledge, progress, freedom and ethical action. Within this problematic, Foucault also attempts to see the role of the thinking subject differently, primarily by recognizing the historical dimension of all human reality.

In elaborating new answers to Kantian questions, Foucault moves to an analysis of the different discursive and non-discursive ways in which 
the subject emerges in history. Genealogy conceives human reality as an effect of the interweaving of certain historical and cultural practices, which it sets out to trace and explore. What is significant in the Foucauldian method is exactly this conceptualization of human reality as practices or technologies which are to be analysed and deconstructed from within. Instead of seeing history as a continuous development of an ideal schema, genealogy is oriented to discontinuities. Throughout the genealogical exploration there are frequent disruptions, uneven and haphazard processes of dispersion, that call into question the supposed linear evolution of history. In this context of reversal, our present is not theorized as the result of a meaningful development, but rather as an episode, a result of struggle and relations of force and domination. Genealogy is the history of such fights, their deep strategies, and the ways that interconnect them.

Foucault (1991c) has argued that within relations of power, individuals and groups can find space to resist domination, exercise freedom and pursue their interests. He has thus drawn a significant line of distinction between relations of power as fields of games where freedom can be exercised and relations of domination which needs resisting. While this distinction overturns arguments that his theorization of power leaves no possibility of freedom, it is, however, a blurring distinction that has created certain tensions in genealogical research that seek to trace specific 'drawings' of this line. As has been suggested: 'where do the various medical, psychiatric and carceral systems of surveillance and discipline, detailed in Discipline and Punish and elsewhere, stand in relation to that distinction?' (Magill, 1997, p. 66). In response I will argue, later in this chapter, that such theoretical questions and philosophical aporias, raised by the use of genealogy, are more effectively worked out in the actual 'writing' of specific genealogies. Whether they are 'solved' or surpassed becomes a task and a challenge for the genealogist.

While, however, genealogy focuses on the war of discourses and power relations, it does not stop there. By revealing discontinuities in the supposed continuous development of history, Foucault's genealogical project also implies a discontinuity in the present social formations. Genealogy is attempting to go further, by tracing possible ways of thinking differently instead of accepting and legitimating what are already the 'truths' of our world. The aim is to provide a counter-memory that will help subjects to recreate the historical and practical conditions of their present existence. This is the future to which genealogies aspire: opening possibilities for life, by separating us from 'the contingency 
that has made us what we are, the possibility of no longer being, doing or thinking what we are, do, or think' (Mahon, 1992, p. 122).

There is today a vast literature related to the genealogical method as well as various readings of it which, although not always outright contradictory, unfold the Foucauldian method in various dimensions. ${ }^{1}$ The bulk of literature that deals with the Foucauldian historiography primarily draws on the 1971 essay 'Nietzsche, Genealogy, History', in which Foucault elaborates the notion of genealogy. In this essay, Foucault depicts genealogy as grey, meticulous and patiently documentary (1986a, p. 76). According to Mahon, it is the colour of the bulk of documents, the 'cyclopean monuments' in Nietzsche's words, that give Nietzschean genealogy its greyness (1982, p. 87).

As opposed to grand historical events, the genealogical search renders itself attentive to details, many of them having remained unnoticed and unrecorded in the narratives of mainstream history. By rejecting the teleological view of history, genealogy celebrates the philosophy of the event. The 'way things are' is just an event, a random result of the interweaving of relations of power and domination. Genealogy as a method of analysis searches in the maze of dispersed events to trace discontinuities, recurrences and play where traditional historiography sees continuous development, progress and seriousness. Therefore, Foucault sees genealogy as an 'eventalization', a method that can attribute different dimensions to the ways traditional historians have dealt with the notion of the event. Eventalization begins with the interrogation of certain evidences in our culture of how things should be: 'making visible a singularity at places where there is a temptation to invoke a historical constant, an immediate anthropological trait, or an obviousness which imposes itself uniformly on all' (Foucault, 1991b, p. 76). This breach of self-evidences also requires a rethinking of the various power relations that at a certain historical moment decisively influenced the way things were socially and historically established. As Foucault notes, this rethinking reveals 'a sort of multiplication or pluralization of causes' (p. 76). This means that the genealogist does not regard singularity as simply an isolated piece of data to be added to his/her documents. The event under scrutiny is to be analysed within the matrix of discursive and non-discursive practices that have given rise to its existence.

McNay (1992, p. 142) has commented that, for Foucault, genealogical historiography avoids the errors of hermeneuticism that are inherent in mainstream forms of historical analysis. As I have already pointed out, one starting point of genealogy is that historically there are no final 
'truths' about our nature or the norms our reason dictates to us and therefore there is no essential, natural, or inevitable way of grouping or classifying people. In this line of analysis, the genealogist does not look beyond or behind historical practices to find a simple unity of meaning or function, or a changeless significance of ourselves and the world around us. The aim is rather to look more closely at the workings of those practices in which moral norms and truths about ourselves have been constructed. Instead of going deep, looking for origins and hidden meanings, the analyst is working on the surface, constructing 'a polygon or rather a polyhedron' (Foucault, 1991b, p. 77) of various minor processes that surround the emergence of the event. What is to be remembered is the fact that the more the analysis breaks down practices, the easier it becomes to find out more about their interrelation, while this process can never have a final end.

Genealogy introduces the problem of how, by becoming constituted as subjects, we come to be subjected within particular configurations. Therefore, what one should excavate in history are the anonymous 'deep' configurations that determine the ways we are classified and grouped, the genealogy of the constitution of our 'politics'.

'Genealogy, consequently, requires patience and a knowledge of details, and it depends on a vast accumulation of source material' (Foucault, 1986a, p. 76). Clearly, the objects of these rigorous analyses are sociohistorical phenomena, as Foucault has pointed out in the above essay (p. 77). What remains unclear is the fundamental nature of the documents under scrutiny. The majority of them rest on the shelves of the Bibliothèque Nationale and the Bibliothèque du Saulchoir where, according to his biographers, Foucault, a real 'archive-addict', spent a great deal of his life. ${ }^{2}$ However, there is something more vivid than pure archive material that animates Foucault's writings. It is accepted that since the very beginning, Foucault's work attracted audiences much wider than the purely academic. For James Miller (1993), it is the philosophical life of the thinker, his active involvement in what he was actually searching and reflecting upon, that accounts for the freshness and timeliness of his themes and ideas. Foucault's 'documents' were also to be found in the asylums, within the political demonstrations occurring outside prisons, or in the baths of San Francisco. Artaud's theatrical plays, the literary work of Battaille, Blanchot's novels, a famous work of art such as 'Las Meninas' or an object such as a pipe could turn out to be objects of his inquiries. ${ }^{3}$ This polymorphous and diverse map of documents and sources leaves future genealogists with an important legacy: that of continually 'inventing' new sources and areas of research, not yet 
thought of by the so-called 'human sciences', which allow us to rethink and call into question the given truths of our world.

Foucault conceives of genealogy as an analysis of descent and emergence and devotes a great deal of reflection to these two terms, tracing their various uses and connotations in the Nietzschean texts. Descent records the true objective of genealogy and is opposed to a pretended unification of the self. Instead of implying a search for origins, the analysis of descent traces the numberless beginnings not easily captured by the historian's eye. As Paul Veyne has lucidly expressed this point:

Foucault has only one thing to say to historians: 'You may continue to explain history as you have always done. But be careful: if you look very closely, if you peel away the banalities, you will notice that there is more to explain than you thought; there are crooked contours that you haven't spotted. (Veyne, 1997, p. 156)

A genealogical analysis of descent does not attempt to reconstruct the past, nor does it trace the effects of past events in the present. In the analysis of descent, the genealogist makes the effort to look directly at what people do, without taking anything for granted, without presupposing the existence of any goal, material cause or ideology. The aim is to strip away the veils that cover people's practices, by simply showing how they are, and where they come from, describing their complicated forms and exploring their countless historical transformations. As Veyne has seen it, practice in Foucault's thought 'is not some mysterious agency, some substratum of history, some hidden engine; it is what people do (the word says just what it means)' (1997, p. 153). Thus, the analysis of descent disturbs previous immobile statements, fragments of unified truths and exposes the heterogeneity of previous consistencies. In the search for descent it turns out that 'truth or being does not lie at the root of what we know and what we are' (Foucault, 1986a, p. 81). This conception is important in establishing the role of genealogy as critique. Finally, the analysis of descent reveals the total inscription of history on the body and everything that touches and surrounds the body. As Foucault notes: 'Genealogy, as an analysis of descent, is thus situated within the articulation of the body and history. Its task is to expose a body totally imprinted by history and the process of history's destruction of the body' (p. 83).

Both French and English-speaking theorists have drawn our attention to the crucial role played by the body in the genealogical method ${ }^{4}$. However, it is in the feminist strand of Foucault scholarship that the 
importance attributed to the body in his thought is particularly underlined and discussed in detail. ${ }^{5}$

The analysis of emergence must delineate the deployment of various processes and power relations in various systems of subjection within which things appeared as events on the stage of history. Emergence is attempting to grasp the very 'moment of arising', in Foucault's words (1986a, p. 83), being aware that this is only an accidental moment, an episode, and not the ultimate point of a historical evolution. 'Emergence is thus the entry of forces' (p. 84), the charting of the battle of forces that resulted in a certain state of affairs. Since anything can just happen in such a battle, 'no one is responsible for an emergence, no one can glory in it, since it always occurs in the interstice' (p. 85).

Genealogy, then, is the analysis of descent and emergence in the sense that these two notions are found in the work of Nietzsche and discussed in Foucault's influential essay. In the genealogist's journey back to history a series of methodological questions emerges: when and how can history be effective? A history renders itself effective when it develops the ability to distinguish singularities, acknowledge differences, decentre [man] as the subject of historical becoming and shatter the certainties of our very existence. Effective history deals with events, 'shortens its vision to those things nearest to it [...] studies what is closest, but so as to seize it at a distance' (Mahon, 1992, p. 89). In such a light, Foucault has seen his project as 'ontology of the present' (Dean, 1994, p. 50), revealing questions of enlightenment as its bedrock. A history of the present is, however, more interested in the future. Calling into question self-evidences of the present by exposing the various ways they were constructed in the past, such histories shatter certain stabilities and help us detach ourselves from our 'truths' and seek alternative ways of existence. Rajchman (1985) has further suggested that by using history to problematize the subject, Foucault has raised the question of freedom, not as a normative category, but as a 'real' situation of being, our possibility of questioning ourselves and modifying the politics of our existence:

Our real freedom does not consist either in telling our true stories and finding our place within some tradition or ethical code, in completely determining our actions in accordance with universal principles, or in accepting our existential limitations in authentic self relation. We are on the contrary 'really' free because we can question and modify those systems which make (only) particular kinds of 
action possible, and because there is no 'authentic' self-relation we must conform to. (Rajchman, 1985, p. 122)

What I have tried to do so far is not a systematization of genealogy. Such an attempt would be at odds with Foucault's own problematization of theoretical and epistemological classifications. Moreover, it is widely acknowledged that in mainstream social and political theory, Foucault's work has been criticized for failing to employ recognizable methodologies. Throughout his life and his work, Foucault persistently resisted being labelled. As a result he has provoked an extraordinary collection of contradictory comments, 'a non-historical historian, an anti-humanist human scientist, a counter-structuralist structuralist' (Dreyfus and Rabinow, 1982, p. xiv) and he himself occasionally made statements that have been quoted over and over again to illustrate the void Foucault created in any philosophical, historical or sociological dictionary of his time and afterwards:

I don't feel it is necessary to know exactly what I am. The main interest in life is to become someone else you were not in the beginning. If you knew when you began a book what you would say at the end, do you think you would have the courage to write it? (Foucault in Martin, 1988, p. 9)

What I have, then, tried to do is to focus on the emergence of genealogy as a set of methodological strategies for research. In doing this, I have come to the conclusion that there is no way of truly understanding what genealogy is about, other than by concentrating on a genealogy per se, analysing it in its minor details, reaching the most remote points of its network, revealing the hidden micro-mechanisms of its operation, grasping the most delicate aspects of its theorization. This is the first stage that inevitably leads to the adventure of writing one's own genealogy. It is through the intermingling of these processes, understanding theory and practising theory that I have come to realize the importance of an incident Jana Sawicki remembers from her 1983 meeting with Foucault at a seminar on technologies of the self at the University of Vermont:

I told him that I had just finished writing a dissertation on his critique of humanism. Not surprisingly, he responded with some embarassment and much seriousness. He suggested that I not spend energy talking about him and, instead, do what he was doing, namely, write genealogies. (Sawicki, 1991, p. 15) 
Therefore, let us now move on to the question of 'how to do a genealogy' and examine how Foucault's work of the 'meta-discursive' ${ }^{6}$ period, can serve as an open paradigm of how a genealogy operates.

\section{Doing genealogy: how?}

Three domains of genealogy are possible. First, a historical ontology of ourselves in relation to truth through which we constitute ourselves as subjects of knowledge; second a historical ontology of ourselves in relation to a field of power through which we constitute ourselves as subjects acting on others; third, a historical ontology in relation to ethics through which we constitute ourselves as moral agents. (Foucault, 1986b, p. 351)

In sketching out the structure of his project Foucault has delineated the triangle of truth-power-ethics in which his research is applied and his genealogies are deployed. These three genealogical domains often meet, inform, overlap and sometimes juxtapose or even contradict each other. In tracing 'the different ways in our culture that humans develop knowledge about themselves', Foucault tried to unmask certain 'truth games' and relate them to specific practices, 'technologies that human beings used to understand themselves' (1988a, pp. 17, 18). As a real cartographer, according to Deleuze (1992b), Foucault again maps out four domains of such technologies: first the technologies of production, which 'permit us to produce, transform, or manipulate things' (1988a, p. 18); second the technologies of sign systems, 'which permit us to use signs, meanings, symbols, or significations' (p. 18); third the technologies of power 'which determine the conduct of individuals and submit them to certain ends or domination, an objectivizing of the subject' (Foucault, 1988a, p. 18) and fourth the technologies of the self, which

permit individuals to effect, by their own means or with the help of others a certain number of operations on their own bodies and souls, thoughts, conduct, and way of being, so as to transform themselves in order to attain a certain state of happiness, purity, wisdom, perfection, or immortality. (Foucault, 1988a, p. 18)

Governing oneself and governing others are interwoven in the problematics that arise from the exploration of the last two sets of technologies, the technologies of power and the technologies of the self. Such an intermingling is particularly evident when pedagogy provides the space and time of their actual operation. 
Foucault's four sets of technologies are therefore placed in the three genealogical domains he has structured for his historical inquiries. The technologies of production and the technologies of sign system are analysed in their relation to truth, which in Foucault is not taken as an absolute notion of transcendental and universal value, but is conceptualized as a genealogy of the multiple truths, or 'regimes of truth' or 'games of truth' of our world. The technologies of power are analysed in the domain of the genealogy of the modern individual as object. Such a genealogy focuses on the processes of objectification of human beings as a result of the exercise of power upon themselves, on both their souls and their bodies. However, it is the analysis of the technologies of the self that reveals the mechanisms through which human beings 'act upon themselves' at the very time of their objectification. The technologies of the self focus on the subjectification of the subject and map the path of the third genealogical territory, that of ethics.

In his discussion of the structure of genealogical interpretation, Foucault (1986b, p. 352) points out the importance of the kind of relationship one has with oneself, which he defines as ethics. As Foucault sees it, there are four aspects of this relationship to oneself. The first is described as 'the ethical substance', the particular domain of the self which is concerned with moral conduct. The way in which people are

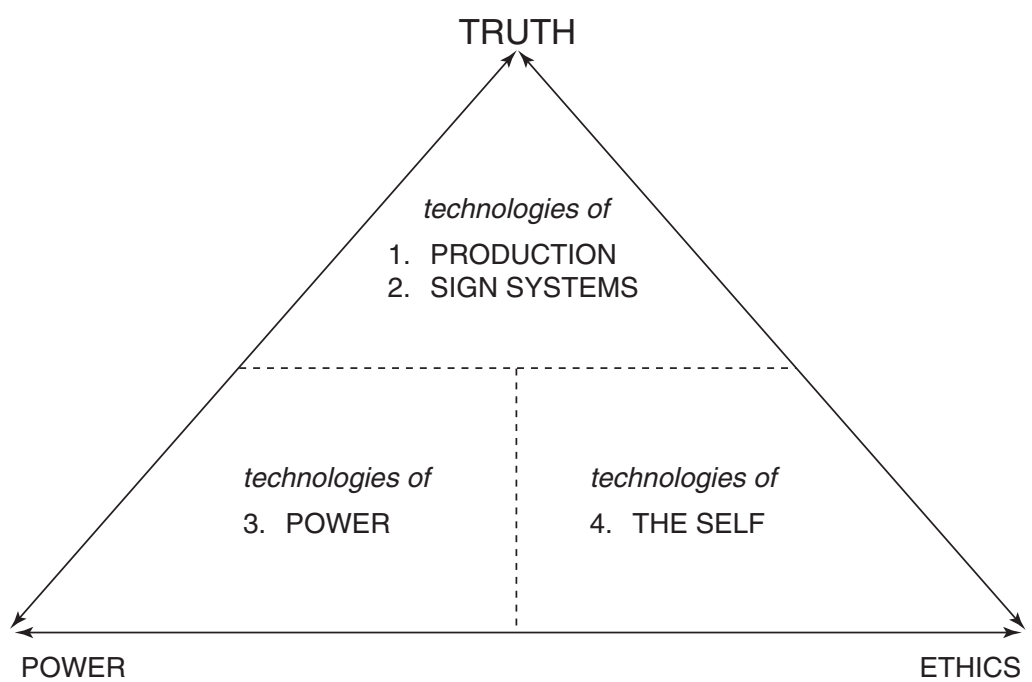


invited to recognize their moral obligation, 'the mode of subjection' in Foucault's words, constitutes the second aspect. The techniques of selfformation, the means by which subjects act on themselves in order to behave ethically, what Foucault calls 'asceticism', is the third aspect of ethics, while the 'telos', the kind of being to which the ethical conducts aims, is the fourth. These four aspects have had different applications in historical periods ranging from antiquity to the modern era.

'Asceticism', the third Foucauldian aspect of ethics, is therefore the area within which technologies of the self, in other words, practices people have used to constitute themselves as ethical subjects, are deployed. An exploration of those techniques cannot, however, be independent from the other three ethical aspects.

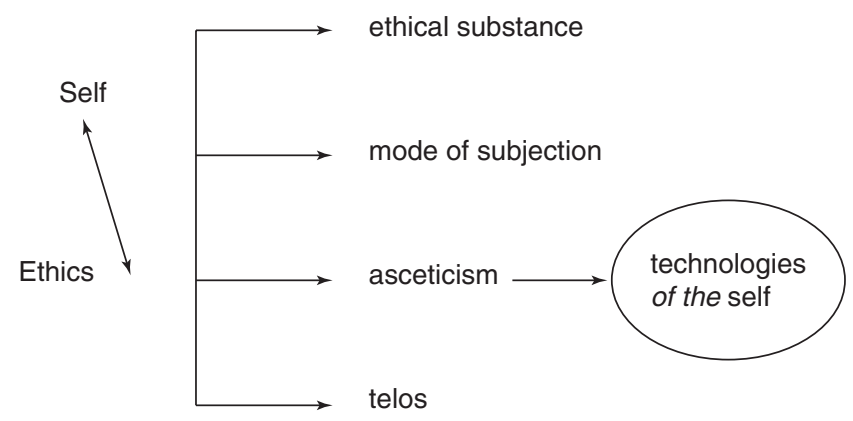

The Use of Pleasure and The Care of the Self are Foucault's only studies about the technologies of the self that were published as books. It is well known that these two books appeared shortly before his death, in 1984, and after Foucault had passed through a long period of contemplation and recollection, which followed the publication of the first volume of his History of Sexuality, in 1976. It was a period during which Foucault's 'passing' to genealogy was theoretically established. It was moreover a period that, as Braidotti has commented, brought forward a new epistemological category: the technology of the subject, 'according to which power produces the real through the processes of normalisation that it adopts and the regions of truth it institutes' (1991, p. 86). It has thus signalled a critical turning point in Foucault's genealogies of the modern subject, by bringing together most rigorously and exemplary, the three genealogical axes of truth, power and ethics, that traverse the whole body of Foucault's analyses. Dews (1989) has seen this period as Foucault's 'late return to the subject'. However, other thinkers speak of 
a redefinition of the subject in Foucault, through a rejection of certain humanist assumptions about its existence (Simons, 1995, p. 78). What feminist analysts have identified as most problematic about the technologies of subjectivity, however, is that the 'self' Foucault theorizes appears as a desexualized and general 'human subject' where gender difference is simply insignificant.

Foucault's most 'mature' and elaborated ideas about the writing of genealogies of the subject are dispersed in various essays, lecture transcripts, interviews and course notes. Technologies of the Self (Martin et al., 1988 ) is a collection of essays, based on the lectures and discussions of the Vermont seminar. Foucault (1988a, p. 16) began his first lecture on technologies of the self at the Vermont seminar by clearly defining sexuality as his dispositif. But, and this is the third question that we now move to:

\section{What is a dispositif?}

Foucault has written that a starting point for 'doing genealogies' should be to focus on a particular problem and then to try to see it in its historical dimension; examining how this problem turned out to be the way we perceive it today: 'I set out from a problem expressed in the terms current today and I try to work out its genealogy. Genealogy means that I begin my analysis from a question posed in the present (Foucault, 1988c, p. 262).

Dreyfus and Rabinow (1982) point out that in searching for the problem the analyst should identify some socially shared 'discomfort' about how things are going. Of course, there is always the problem that not all social groups can have shared concerns. The perspective of the analyst is decisive in focusing on a particular problem, and this should be admitted and used by the analyst in an attempt to deconstruct possible arbitrary personal feelings and stances with regard to his/her project. In 'Nietzsche, Genealogy, History' Foucault wrote that genealogy is effective history understood as the 'affirmation of knowledge as perspective'. As Simons has commented, 'the perspective affirmed is that of those who resist' (1995, p. 91).

Following the first step of isolating the problem, the analyst is tracing the current practices that could relate to the diagnosed 'problem' and finally s/he is trying to formulate the network of relations between the practices and the problem. Situating the problem in a system of relations that can account for the socially shared discomfort is a turning point for 'doing genealogy' and is immediately related to the Foucauldian methodological concept of dispositif, a term that has been translated in 
English as apparatus and which was first used by Foucault in Discipline and Punish, but was mostly elaborated in the History of Sexuality. ${ }^{7}$

As Foucault sees it, a dispositif is a system of relations that can be established between heterogeneous elements, discursive and non-discursive practices, 'the said as well as the unsaid' (1980a, p. 194). A dispositif can include 'discourses, institutions, architectural arrangements, regulations, laws, administrative measures, scientific statements, philosophic propositions, morality, philanthropy, etc.' (p. 194). There is always 'an urgent need' (p. 195) to which the functioning of the dispositif responds: 'the dispositif is essentially of a strategic nature, which means assuming that it is a matter of a certain manipulation of relations of forces, either developing in a particular direction, blocking them, stabilising them, utilising them, etc.' (p. 196). Being inscribed in a play of power, the dispositif also relates to certain types of knowledge which derive from it, but also condition it. In Foucault's view, therefore, the analyst has a dispositif when $\mathrm{s} / \mathrm{he}$ has succeeded in isolating a cluster of power relations sustaining, and being sustained by, certain types of knowledge (p. 196).

Following the 'announcement' of his dispositif, Foucault puts together the different elements 'discursive and non-discursive', that concerned him in sketching out the diagram of his inquiries to conclude that: 'I asked myself: How had the subject been compelled to decipher himself in regard to what was forbidden? It is a question of the relation between asceticism and truth' (Foucault, 1988a, p. 17). It is significant that a genealogy should start with a major interrogation of what has been accepted as the 'truth', any truth concerning the ways individuals understand themselves as subjects of this world. The genealogy thus starts by shattering any certainties, without this questioning being a rhetorical one, asking so as to present pre-existent answers. In posing genealogical questions one can never be sure that s/he could ultimately find any 'satisfactory answers'. This is the risk, the adventure and the fascination of the exercise. As is well known, Foucault himself never finished his genealogical work or came to any conclusion or overall theory about the technologies of the self that he was researching during the final decade of his life.

In Foucault's analyses there are two basic themes that traverse the nexus of the technologies of the self: governmentality and aesthetics. These two themes saturate Foucault's reflections upon the cultivation of the self and reveal the problem of truth, 'the truth concerning what one is, what one does and what one is capable of doing' (Schmid, 1994, p. 68), as the kernel of the problematizations around the formation of the ethical subject. 
Foucault has used the term governmentality to refer to the 'contact between the technologies of domination of others and those of the self' $^{\prime}$ 1988a, p. 17). The analysis of governmentality is deployed along two Foucauldian genealogical axes, power and ethics. Governmentality is therefore considered as a relationship between the ability of individuals to control themselves and their ability to control others.

The concept of aesthetics derives from antiquity, but Foucault has largely adopted Nietzsche's elaboration in his approach. His conception of an aesthetics of existence is largely influenced by the demands of creating a style for one's life, making claims for the empowering and transgressive possibilities of art and resisting the very present of existence:

What strikes me is the fact that in our society, art has become something which is related only to objects and not to individuals or to life. That art is something which is specialised or which is done by experts who are artists. But couldn't everyone's life become a work of art? Why should the lamp or the house be an art object, but not our life? (Foucault, 1986b, pp. 350-1)

Foucault's urge for the need to create a form, a style for one's life has provoked intense objections about its supposed utopian and elitistic character. Thacker (1993) has argued that human beings and 'real life' is not at all like the lamp Foucault mentions in his notorious saying. McNay has also problematized Foucault's discussion of aesthetics in relation to Baudelaire's account of the dandy who becomes 'modern' simply because he refuses to compromise with the constraints of his era, the nineteenth century, and dares to invent and construct a 'new' self $(1994$, p. 149). But does Foucault have in mind a certain aesthetic model, a notion of a beautiful subjectivity that resembles a work of art like the famous lamp or the heroic Baudelarian dandy?

Simons (1995, p. 76) has discerned three central themes in the Foucauldian aesthetics of the self. First in his list come the demands of style which Simons conceives as a never-ending struggle for transgressing the limits that constrain but at the same time define the very existence of human beings, since death appears to be the only experience without limits. The demands of style are directly related to the second theme, that of the artistic practice as a source of empowerment. This theme further elaborates the Foucauldian approach to a transgression of limits through the possibilities created by art. ${ }^{8}$ The art of living is therefore founded on the decisive role of the individual in both interrogating one's present, working upon one's life and acting politically for the enhancement of this 


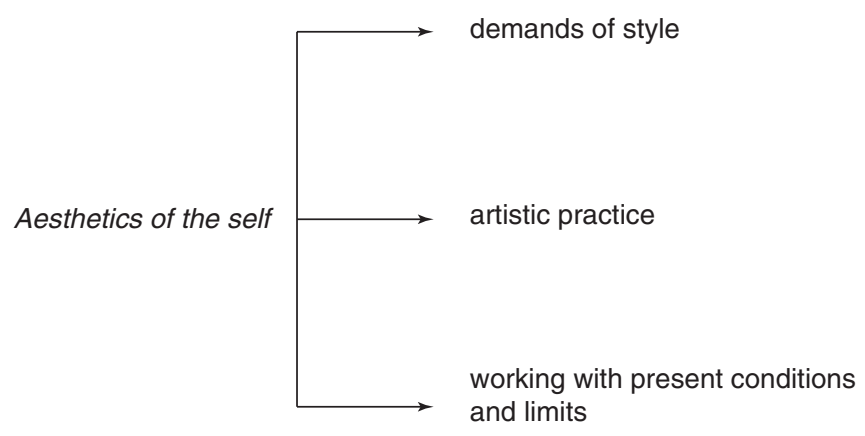

very life. This conception underlines the necessity of self-government as the kernel of an aesthetics of existence and leads to the third theme Simons has defined as working with present conditions and limits. These three themes, the demands of style, the artistic practice as a form of empowerment and working with present conditions and limits rest upon the Enlightenment roots of Foucault's work:

Considering the ways in which Foucault has questioned and problematized themes around the organization of existence, it is difficult to deny that ethics are founded on aesthetics. I will agree with Schmid that the question seems quite capable of being reversed: if not on aesthetics then on what can we found ethics?

\section{What are the possibilities of becoming 'other'?}

A deployment of Foucault's techniques and practices can never be exhaustive or final. Foucault's originality lies in his strategic use of different discourses and approaches in the writing of his genealogies. Each reading of these genealogies reveals hidden layers of attentive and detailed research of an immense variety of data. Rather than following methodological principles, Foucault's genealogies create a methodological rhythm of their own, weaving around a set of crucial questions, already introduced at the beginning of this chapter: What is happening now? What is this present of ours? How have we become what we are and what are the possibilities of becoming 'other'? Such questions create unexplored and even unthought-of areas of investigation. Foucault's genealogies do not offer methodological 'certainties'. They persistently evade classification, but they do inspire the writing of new genealogies to interrogate the truths of our world.

As a genealogical endeavour pursuing Foucault's intellectual adventures, this chapter is inevitably led to consider a crucial question: what 
about those human beings under scrutiny? What happens if they stop being 'neutral'? Instead of joining those critics that point to the explicitly unsexed, but implicitly male human beings of Foucault's genealogies, I would rather direct my inquiries towards 'sexing the self' of the technologies. In her project of 'sexing the self', Elspeth Probyn stresses the necessity for contemporary feminist theory to develop an attitude, 'a mode of relating to contemporary reality' (1993, p. 109), at the same time that it opens up genealogical inquiries that will lead to the deployment of subjectivities that are historically and culturally specific. Although she acknowledges the difficulties arising for feminists meeting Foucault, she cites Weeks and the possibility he points out 'for inflecting dominant codes' (p. 166) without being obliged to accept all of Foucault's positions. Contemplating the various procedures involved in the creation of the self, Probyn focuses on the way Foucault understands the technologies of the self as 'an order of levels of different types of events' and the possibilities opened up for an active intervention. Here she draws on Deleuze's idea about the folding and unfolding of a self realized as a form to be moulded (p. 126). Since Deleuze's major political proposition has been on how to make connections and open up new planes of thinking (Rajchman, 2000), the focus of this chapter has already moved to the second plane of the initial analytical triangle - namely, critical feminisms.

\section{Dangerous liaisons: genealogies and critical feminisms}

But it must be said first off, and hence the title of this essay, [The Technology of Gender] that to think of gender as the product and the process of a number of social technologies, of technosocial or bio-medical apparati, is to have already gone beyond Foucault, for his critical understanding of the technology of sex did not take into account its differential solicitation of male and female subjects, and by ignoring the conflicting investments of men and women in the discourses and practices of sexuality, Foucault's theory in fact, excludes, though it does not preclude, the consideration of gender. (de Lauretis, 1987, p. 3)

As the above quote clearly illustrates, feminist theorists have critically interrogated Foucault's work as unconcerned with gender issues. There is no doubt that a careful reading of his work fully justifies these feminist arguments. Foucault has made very few direct references to women's issues. In the 'Afterword' of Dreyfus and Rabinow's influential 
study Beyond Structuralism and Hermenenutics, Foucault (1982a, p. 211) refers to the 'opposition to the power of men over women' as an example of a series of 'antiauthority struggles' which he sets out to examine in detail. Better known has been his attentiveness to the 'hysterization of women's bodies' in the first volume of his History of Sexuality and the way in which he presents women's bodies colonized by the medicoscientific discourses of the era in a 'threefold process' whereby they were sexualized, pathologized and incarcerated within the disciplinary institution of the family (Foucault, 1990a, p. 104).

Foucault's blindness to the specificity of gender issues rests upon his not taking an essentialist position with regard to the formation of any subjectivity. In 'The Confession of the Flesh', Foucault notes that 'the real strength of the women's movement is not that of having laid claim to the specificity of their sexuality and the rights pertaining to it, but that they have actually departed from the discourse conducted within the apparatuses of sexuality' (1980a, p. 211). What he finds 'creative and interesting' about the women's movement, is what he describes as 'a veritable moment of desexualization' (p. 212). This is the process whereby the women's movement, departing from its initial focus on sexual difference - which was historically specific and bound to the necessity to mark their presence on the political map - moved on to challenge discourses, power relations and social practices sustaining the sex/gender system within which they were unequally positioned. We could argue here, of course, that this process of going beyond the constraints of the dispositif of sexuality has been an ongoing and difficult one. The feminist movement that, in Foucault's perception, has so gloriously eliminated of the sexualization of its claims has also always been caught in a paradox. As Joan Scott has argued: 'in order to protest women's exclusion, [feminists] had to act on behalf of women, and so invoked the very difference, they sought to deny' (1996, p. x).

Foucault has also been criticized for taking direct anti-feminist positions. His arguments about the punishment of rape as a crime against humanity, a power crime and not a specifically sexual one, have certainly formed the political core of the attacks his work has received from feminists. ${ }^{9}$

Against this background, why did I choose to draw on Foucault's work in my explorations of the female self? Foucault's writings have been an arena for conflicting interpretations. It is certainly the case that his work cannot be taken as a totalizing theory. As has been suggested, 'it is difficult to talk about Foucault in the singular' (Mills, 1993, p. 7). A secondary reading of his work reveals a number of themes that have 
been picked up by feminists who have discovered mutual points of problematization as well as common areas of concern with Foucault. First in the list of such crossing points comes the 'old' feminist position that 'the personal is political', which in the micro-political analysis that the genealogical research proposes, finds strong grounds to be deployed as both a stance and a methodology. As I have already mentioned in this chapter, Foucault's focus on bio-politics and his problematization of everything about and around the body have opened large areas of research and interest concerning the various ways the female body has been moulded, constructed and exploited in human history.

There is, in fact, a considerable and growing amount of feminist literature either dealing directly with Foucault or drawing on his work. ${ }^{10}$ In keeping to the genealogical project of drawing maps, I will therefore use this theoretical field to frame a cartography of critical feminisms, those feminist positions which, according to Braidotti (1991), have attempted to express the female self as incomplete, plural, fragmented and yet rooted in her bodily reality. Therefore it is to the stage of feminist critical theory that the lights are now falling.

Diamond and Quinby (1988) have seen Foucault's work as a 'hand of help' in the political defence of feminism and have talked about the possibility of a friendship grounded in political and ethical commitment, creating positions open to critical dialogues. They have underlined Foucault's discourse-theory and his focus on the body as two of four points of convergence between Foucault and feminism, the other two being his methodological suggestion for micro-analysis, attending to everything that is local, intimate or personal, and finally his questioning of universalisms, especially in the way they privilege the Western white masculine elite. In their analyses, resistance is the point where these four themes converge. In relation to the Foucauldian approach to the body, however, interesting feminist challenges have also arisen. Judith Butler sees contradictions in Foucault's conceptualization of the body and the role of history in connection with the body (1990, p. 133).

Chris Weedon (1987) has considered Foucault's theorization of the subject as the most interesting area of his work, for feminists. As Weedon points out, the subject in Foucault's thought is socially constructed in discursive practices, but, at the same time, able to reflect upon these very discursive relations that constitute it, capable of resistance and able to choose from the options produced out of the clash between contradictory subject positions and practices.

Gendering the subject debate, Teresa de Lauretis (1987) draws on Foucault's conceptualization of sex as a technology, but criticizes his 
lack of interest in the different implications such a technology can have on male and female subjects. She proposes that gender as a form of representation and self-representation is constructed by various social technologies, power relations, discourses, epistemologies, as well as everyday practices (p. 2). But, as the above quote from her influential essay 'Technologies of Gender' indicates, de Lauretis points to the fact that Foucault's notion of sex cannot account for the complex processes within which gender is constituted as a technology. This is the project she undertakes, making four propositions for the analysis of gender as a technology: first that gender is a representation, second that it is actually constructed through representation, third that the construction of gender is a historical process that goes on to the present and finally that gender is even constructed through the very practices of its deconstruction (p. 3). In de Lauretis' view, gender is a representation not of an individual, but of a social relation, actually constructing the very relation it represents. This construction is placed within the conceptual structures of what Gayle Rubin (1975) has defined as the sex/gender system. ${ }^{11}$ Within this semiotic system of social positions carrying differential meanings, de Lauretis finally argues that 'the construction of gender is both the product and the process of its representation' (1987, p. 5). De Lauretis draws on Althusser's notion of ideology to elaborate her argument of gender as a representation and to argue that 'gender [ideology in Althusser] represents not the system of the real relations which govern the existence of individuals, but the imaginary relations of those individuals to the real relations in which they live and which govern their existence' (1987, p. 6). She goes on to explore how the ideology of gender evolves in feminist theory, particularly focusing on 'Althusser's formulation of the subjective working of ideology', the fact 'that ideology, needs a subject to work on' (p. 9). This, according to de Lauretis, is critically important in suggesting that: 'the construction of gender is the product and the process of both representation and selfrepresentation' (p. 9) [my emphasis]. As will further be discussed in this chapter, adding self-representation to the cartography of the construction of gender has been a crucial theoretical offering for feminist theorizations of women's autobiographical practices as technologies. De Lauretis is further concerned with Althusser's notion of interpellation, 'the process whereby a social representation is accepted and absorbed by an individual as her (or his) own representation, and so becomes, for that individual, real, even though it is in fact imaginary' (p. 12). So the question de Lauretis poses is 'not only how the representation of gender is constructed, by the given technology, but also how it becomes absorbed 
subjectively by each individual whom that technology addresses' (p. 13). In exploring this question de Lauretis draws on feminist film theory, borrowing the concept of spectatorship to show how the spectator's engagement with a film has always been highly driven by her gender. The critical analyses of female spectatorship, according to de Lauretis, further highlight how the supposedly gender-neutral historical construction of sexuality in Foucault's analyses fails to address the question of why male and female subjects have had different investments in the dominant discursive positions of the (hetero)sexuality apparatus, not only between themselves, but also, and most importantly, amongst themselves. Here, de Lauretis points to Hollway's (1984) reworking of the Foucauldian productive power as the motor driving 'individuals' investments in discursive positions' (de Lauretis, 1987, p. 14). This reconceptualization of power allows for an agentic subject to emerge and this is the line de Lauretis takes to put forward the path-breaking notion of the female feminist subject, or 'subject of feminism', which, in contrast to the Althusserian subject, which is always caught within ideology, can move in and out of the gender circuit, 'at once within and without representation' (1987, p. 10). She further argues that a feminist theory of gender should conceive this subject as multiple, contradicted and heteronomous in relation to the social and cultural conditions that tend to define, control and dominate its very existence:

The construction of gender goes on today through the various technologies of gender (e.g. cinema) and institutional discourses (e.g. theory) with power to control the field of social meaning and thus produce, promote, and 'implant' representations of gender. But the terms of a different construction of gender also exist, in the margins of hegemonic discourses. Posed from outside the heterosexual social contract, and inscribed in micropolitical practices, these terms can also have a part in the construction of gender, and their effects are rather at the 'local' level of resistances, in subjectivity and selfrepresentation [my emphasis]. (de Lauretis, 1987, p. 18)

As will be discussed further, it is at the 'margins of hegemonic discourses' that women's practices of self-representation have emerged, therefore creating ruptures in the tradition of writing the self, and offering instances of 'becoming other'. It is on the 'local' level of resistances in subjectivity and self-representation that feminist theorists have further problematized the subject within a Foucauldian framework. Judith Butler (1990) has interrogated the naturalness of being female and she has 
looked into the ways gender is constituted through discursive and performative acts. She has further critically theorized how subjection functions as a paradoxical form of power in the constitution of the subject (Butler, 1997). Butler argues that feminist politics need not be grounded on a notion of primary identity, in order to become radical and subversive. In the same vein, Donna Haraway $(1990,1991)$ considers women as sets of fractured identities, which seem 'contradictory, partial and strategic', and stresses the lack of any essential criterion for identifying women as an entity. In her analysis of new technologies and feminist politics, she draws on the specificity of the situation of women of colour to interrogate the collective subject, the 'we' of feminism: 'Who counts as "us" in my own rhetoric? Which identities are available to ground such a potent political myth called "us", and what could motivate enlistment in this collectivity?' (1990, p. 197). She points to the fact that the fiction of the unitary female self, instead of being liberatory, has rather functioned as a pretence to reproduce hierarchies and inequalities among women.

Keeping the tension between the celebration of differences and the political necessity of unity, critical feminists acknowledge, however, the possibility of forming coalitions, affinities rather than identities, in response to specific historical moments of resistance. In response to these tensions and aporias, Haraway has developed an epistemological project which rejects the validity of global theorizations and suggests the perspectival standpoint of 'situated knowledges':

We seek not the knowledges ruled by phallogocentrism (nostalgia for the presence of the one true Word) and disembodied vision, but those ruled by partial sight and limited voice. We do not seek partiality for its own sake, but for the sake of the connections and unexpected openings situated knowledges make possible. The only way to find a larger vision is to be somewhere in particular. (1991, p. 196)

Tracing paths of feminists encountering Foucault has not been easy. Sometimes it has proved painful in terms of the theoretical and political dilemmas it has actually raised. Haraway's suggestion for the possibility of forming coalitions has been helpful in this respect, and it is at this point that Rosi Braidotti's work $(1991,1994)$ has opened up theoretical grounds for such political and theoretical coalitions to be constructed.

Braidotti attempts to bridge the gap between the critical notions of 'sexual difference' and 'gender' and the long-standing debate they have introduced in the feminist theorizations of subjectivity. Drawing on 
de Lauretis' (1987, p. 2) critique of the problematic status of sexual difference in terms of the constraints it imposes on the conceptualization of differences within women and the theorization of the subject as multiple and contradicted, Braidotti (1994, pp. 159-69) maps difference on three interdependent levels; first, differences between men and women; second, differences among women; and third, differences within each woman. This three-level analysis of difference seems to be in line with what de Lauretis has suggested feminist theory is about:

Feminist theory is all about an essential difference, an irreducible difference, though not a difference between man and woman, nor a difference inherent in 'woman's nature' (in woman as nature), but a difference in the feminist conception of woman, women and the world. (de Lauretis, 1991, p. 209)

This three-layer difference further becomes, for Braidotti, the basis for the development of Deleuze and Guattari's (1988) notion of nomadism as a project to encompass multiple, female, embodied subjects in the process of becoming, but I will further consider the implication of nomadic subjects in the deployment of the technologies of the female self, in the last chapter of this book.

Diving to the deep blue sea of various feminist readings and interpretations of Foucault, this study has particularly been concerned with those works of feminists who have theorized the female subject as multiple, collective and in a process of becoming. Here, I think the theoretical standpoints of Teresa de Lauretis, Elspeth Probyn, Judith Butler, Donna Haraway and Rosi Braidotti have been particularly influential and I will draw on them, in the exploration of the technologies of the female self. As Braidotti (1991) has suggested, these feminist positions, despite their theoretical variations, belong to the already mentioned forum of what she has called feminist critical theory. Braidotti has used this term to refer to the feminist analysts who have worked towards redefining the female subjectivity on both an epistemological and a political level:

The focus on subjectivity results in the definition of feminism as an epistemological struggle as well as a struggle of political nature. In this framework epistemology means the political process of comprehending and redefining the woman as a subject of knowledge, and of inscribing these changes into a new social and historical reality for women. (Braidotti, 1991, p. 210) 
So far, then, I have looked closer at Foucauldian genealogies and critical feminisms and have elaborated the idea of having them 'translated' to technologies of the self and technologies of gender respectively. However, how are they both linked to the autobiographical project? Although some links have already been traced, the discussion of this chapter now follows connecting lines on the third plane of the discursive analytical triangle: women's practices of self-representation.

\section{Histories of the self: the autobiographical encounter}

Autobiography demonstrates that we can never recover the past, only represent it; yet it encodes the possibility of recovery as desire and the possibility of representation as its mode of production. The autobiographical $\mathrm{I}$ is at home in both history and narrative because it is produced by the action that draws those fields together. (Gilmore, 1994, p. 86)

In moving to the third plane of the analytical triangle, what I want to explore in this section is how Foucault's genealogies of the modern subject and feminist analyses of women's autobiographical practices can be put on a map of rhizomatic formations ${ }^{12}$ for the deployment of the genealogical project: reflecting on the present, problematizing its historicity, imagining different futures. Rhizomatic formations in Deleuze and Guattari's influential work are analytical systems or rather machinic assemblages, ${ }^{13}$ which are not rigidly defined and closed; they are rather open planes, where thought is on the move, always making connections with new planes of thinking. I have found Deleuze and Guattari's concept of rhizomatic formations very useful in terms of sustaining the triangular theoretical proposition that I have put forward in this study: using women's autobiographical practices for the writing of feminist genealogies. I have seen this triangle as an open assemblage of different lines of thinking, which, instead of being static, always keep moving, waiting for 'the unknown knocking at the door' (Deleuze, 1992b, p. 165), being attentive to 'the thought from the outside' (Foucault, 1987b).

In this state of moving lines, the genealogical turn in the study of subjectivities is making connections with the feminist project of rewriting the female self into history: 'a sense of that which is lost, never to be recovered completely, has been one of the most powerful rhetorical devices of modern women's history' (Steedman, 1989, p. 104). Indeed, reflecting on women's history has been a primary concern of feminist theories and has highlighted contemporary problematics around the 
speaking subjects of history: 'to see where autobiography is placed is to begin to see, indeed, who speaks for History' (Swindells, 1989, p. 28). It further seems that women's history has a particular investment in autobiography 'as a previously unacknowledged mode of making visible formerly invisible subjects' (Smith and Watson, 1998, p. 5). Carolyn Steedman $(1989,1992)$ has looked into women's autobiographical writings, to trace the deployment of the female self in its historical dimension. Her own autobiographical testament, Landscape for a Good Woman: a Story of Two Lives (1986), has become a canonical reference for a range of feminist theories problematizing what can and/or cannot be represented through autobiography (Probyn, 1993; Gillmore, 1994, Smith and Watson, 1998, 2001; Cosslett et al., 2000; Anderson, 2001). What I want to suggest here is that women's autobiographical practices have opened up a field for a genealogical analysis of the conditions of possibility for the female self to emerge in history. As already indicated in this chapter, one of the key processes in genealogy is its focusing on insignificant details, on what has been sidelined or kept silent. Seen, therefore, from a genealogical perspective, women's self-writings emerge from the grey spheres of history to give voice to experiences long unattended and discredited. However, the feminist project of rewriting women's experiences into history has been critically interrogated in light of the problematization of the very notion of experience and its supposed privileged explanatory capacity. Joan Scott has argued that women's experiences should be considered as discursive constructs, rather than undisputable points of reference for feminist historians. Scott's influential work has opened up new directions in the use of 'experience' in the writing of history:

Experience is at once always already an interpretation and something that needs to be interpreted. What counts as experience is neither self-evident nor straightforward; it is always contested, and always therefore political. (Scott, 1991, p. 797)

What is mostly highlighted in Scott's essay is the theoretical and political need for experience to be deconstructed and for the analyst to be situated. In the light of these problematics, women's practices of self-representation, be they autobiographies, memoirs, diaries, journals, or letters, cannot be taken as indisputable historical documents, but rather as discursively constructed texts, which, however, have recorded and revealed various and significant processes in the construction of the female self. In this way, these autobiographical texts can provide a vital 
entry point for exploring the historical dimension of women's present condition, the genealogy of their becoming. I therefore suggest that the female textual selves, fragmented and incoherent as they are, can give the analyst lines towards genealogizing women. Studying women's autobiographical writings either unpublished or long-out-of-print, can be an ongoing genealogical exercise, towards a re-evaluation and reorganization of the historicity of women's actuality. Clearly, giving women a genealogical history does not claim to reconstruct their past 'as it really was'. It is rather an attempt to reveal the temporality and contingency of contemporary 'truths' by tracing how they were constructed in certain historical periods. It is the Foucauldian idea of a history starting from the present and attaining to the future that has driven my will to write genealogies of the female self. Perceiving the contingency of discourses and practices that construct contemporary 'realities', seems a useful way of distancing ourselves from certain self-models socially imposed and highly restrictive today.

Having charted lines connecting women's autobiographies with genealogical and feminist histories, I will now turn to a plane of analysis, where genealogies and feminist theorizations of subjectivities form rhizomes with the autobiographical tradition of writing the self. In the genealogical framework of technologies of the self, writing is considered as vitally important. "The self is something to write about, a theme or object (subject) of writing activity' (Foucault, 1988a, p. 27). Writing, truth and power are forcefully interwoven in the matrix of self-technologies: searching the 'truth' for the self through writing, recording these truths as a reservoir for an ongoing process of acting upon the self and of acting upon others. Writing the self is therefore a practice within a wider set of technologies through which the genealogical axes of truth, power and the self converge. Writing is a technology of the self, albeit not an unproblematic one. As Leigh Gillmore has suggested, it is an area constructed out of conflicts and 'eruptions' that seem to come to the fore more forcefully when gender 'interrupts' the tradition of writing the self (1994, p. 45).

As a technology of the self, writing has been a crucial theme in feminist explorations of the subject. Indeed, over the past twenty years a wide range of feminist work has theorized women's practices of selfrepresentation, recovering their position in the literary autobiographical genre. Sidonie Smith and Julia Watson (1998) have mapped this field of feminist theories of women's autobiographies, tracing three significant stages in its deployment: 'building the archive of women's writings, claiming models of heroic identity and revising dominant theories of 
autobiography' (1998, p. 5). It is within the third stage, revising dominant theories of autobiography, that the feminist analyses my study draws on, are situated. As already indicated, what has emerged as an area of theoretical consideration par excellence within this field, is the problem of experience and representation, the discussion and problematization of "the assumption that "experience" is unproblematically "real" and "readable" and can be captured transparently in language expressing the truth of experience' (Smith and Watson, 1988, p. 9). The genealogy of feminist theorizations of autobiography carries the marks of this transition from the celebration to the problematization of women's experiences. Estelle Jelinek's Women's Autobiography: Essays in Criticism (1980), which was significant in the opening of this critical field, theorized autobiographical texts as unproblematically referential. Seven years later, however, in The Female Autograph (1987) Domna Stanton excised bio, that is life, from autobiography, foregrounding the problematic relationship between lived experiences and their textual representation and opening up a line of feminist theorization of the autographical subject (Gillmore, 1994; Perrault, 1995). Within the discursive regime of the second wave feminism, Jelinek mapped women's and men's autobiographies as two contrasting territories, highlighting and rather overemphasizing sexual difference in the way they are constituted. She therefore identified certain quasi-universal characteristics and differences between them: women's writings of the self appear discontinuous, incoherent, irregular and full of personal concerns as opposed to the linear, chronological and coherent male writings, which deal dynamically with personal achievements within the public sphere. This fragmented, incoherent, open self represented in women's autobiographical practices is further differentiated from the monadic and universal self of the male autobiographical tradition; the latter appears to evolve in the text in a procedure that looks natural to himself as well as to the others, a man as 'a representative of the time, a mirror of his era' (Brodzki and Shenk, 1988 , p. 2). In contrast, the female self is constituted in its relation to others, it is a dependent social self, differentiated from the independent, self-contented paradigm of the male tradition; there are always conflicts with everything that relates to the unfolding of this female self, starting with the very act of writing. There is no doubt that there are indeed differences and variations in the autobiographical tradition and these differences have been marked by gender, but not only; 'race' and ethnicity, class, and sexual orientation, to name but the obvious, are important sources for the construction of differences. These differences, however, although not totally ignored, have been downplayed in the initial stages 
of feminists' revisioning of the autobiographical tradition (see Smith and Watson, 1998). In this light, and while keeping the importance of the different ways of writing the self within her theoretical project, Stanton attempted not to use difference as a way of essentializing the binarism between 'masculine' and 'feminine' ways of writing the self; she rather used it as a lens to look at the historical and cultural specificity of women's writings. She thus focused her interest on differences within women's writings, arguing that in terms of its referentiality women's autobiographies, or 'autogynographies', should be considered as an un-ended, fragmentary, and heterogeneous mixture of discourses and histories. Smith and Watson have stressed the importance of keeping complexities open by considering simultaneously how multileveled differences of sex, gender, 'race' and ethnicity are interwoven in the constitution of the autobiographical subject (1998). Their work is therefore in line with the feminist project of the three-level theorization of difference - differences between women and men, among women but also within each woman - which we have seen elaborated in de Lauretis' and Braidotti's work, earlier on in this chapter.

To return to the project of writing as a technology of the self, what I think has been particularly interesting in Stanton's argument is that the female subject constitutes herself through writing. In rewriting her life, the author of the female self does not produce an autobiography but a female autograph. ${ }^{14}$ The construction of the autograph, independent from its referentiality to the bio/life of the subject is, I suggest, critical in the genealogical analysis of the discursive conditions that made this constitution possible; it is therefore an important line making rhizomatic connections between genealogies, critical feminisms and autobiographies.

Having made full circle to the discursive analytical triangle I have initially offered as a theoretical field for making connections, I now want to look more closely at Gilmore's (1994) theorization of autobiographics, her analysis of the technologies of autobiography. Following Foucault's notion of technologies of the self and de Lauretis' (1987) proposition of gender as a representation, as technologies of gender, Leigh Gilmore (1994) has seen autobiography - or rather in the term she has coined autobiographics - as a discursive regime, a matrix where narratives of truth and experience are knitted together, further theorizing women's practices of self-representation as technologies of autobiography:

I offer the term autobiographics to describe those elements of selfrepresentation, which are not bound by a philosophical definition of 
the self derived from Augustine, not content with the literary history of autobiography, those elements that instead mark a location in a text, where self-invention, self-discovery, and self-representation emerge within the technologies of autobiography- namely, those legalistic, literary, social and ecclesiastical discourses of truth and identity through which the subject of autobiography is produced. Autobiographics as a description of self-representation and as a reading practice, is concerned with interruptions and eruptions, with resistance and contradiction as strategies of self-representation. (Gilmore, 1994, p. 42)

In the same line that gender is a representation (de Lauretis, 1987), Gilmore argues that 'the autobiographical subject is a representation and its representation is its construction [...] it is produced not by experience but by autobiography' (1994, p. 25). It would therefore seem here that Gillmore's suggestion is in line with Stanton's proposition of the autographical subject, who constitutes herself through writing (1987). However, what the genealogical analysis highlights in the constitution of the textual self, is the importance of "the material consequences of being interpellated as "woman" or as a member of the category "women" by discursive and juridical systems' (Gillmore, 1994, p. xiii). Moving within, but also beyond the textual realm, genealogy places the autobiographical practices of writing the self in a cartography of polyvalent and multifarious historical transformations, depicting the conditions of possibility for the 'figure' of the woman to emerge (Foucault, 1990a). This self is a discursive formation, neither purely textual, as in Stanton's theorization, nor unproblematically real and readable, as in Jelinek (1980). It is rather the self that de Lauretis (1987) has seen as emerging from the interstices and margins of hegemonic discourses, in what can be represented, but also in what is left without or beyond representation. As Gilmore explains, this movement beyond representation is not something that becomes a possibility for the female subject as a result of 'some privileged relation to nature or the supernatural' (1994, p. 12). It is rather an effect of what Foucault has described as the arising of reverse discourses, the 'complex and unstable process whereby discourse can be both an instrument and an effect of power, but also a hindrance, a stumbling-block, a point of resistance and a starting point for an opposing strategy' (1990a, p. 101). Autobiography is indeed a discursive regime creating the conditions of possibility for counter-discourses to arise and unruly subjects to emerge. These unruly subjects follow routes of estrangement from master narratives becoming 'vectors of deterritorialization' 
for Deleuze or resisting figures for Foucault. As Gilmore asserts, 'even in the narrowest and most ambivalent sense, writing an autobiography can be a political act because it asserts a right to speak rather than to be spoken for' (1994, p. 40). In Cavarero's (2000) philosophical conceptualization of the narratable self, narration, both biographical and autobiographical, is a political act in its capacity to expose the fragile uniqueness of the self in its constitutive relation with others.

\section{Making connections}

The feminist project of recovering women's presence in history seems to be in line with the genealogical interest in peripheral histories and subjugated knowledges. Women's marginalized and forgotten autobiographical texts constitute a set of extremely rich genealogical data, the dusty and grey documents of the meticulous archival research, the genealogical field par excellence. Moreover the role of autobiography in the constitution of the female subject seems to resonate with Foucault's analyses of the role of writing in the technologies of the self. However, as already noted, this happy encounter has been decisively shaken by the problematic relationship between experience and the autobiographical subject. Women's experiences, and indeed any experience recorded in autobiographical narratives, or elsewhere, already include processes of selection, through which some moments have been remembered, while others have been forgotten. The act of remembering or forgetting is active rather than passive, creating meanings through various interpretations of past experiences. ${ }^{15}$ As has been suggested, memory is indeed a complex and problematic area amongst 'the constitutive processes of autobiographical subjectivity' (Smith and Watson, 2001, p. 15). Smith and Watson have offered a multilevelled study of memory, interrogating its status as 'both source and authenticator of autobiographical acts' (p. 16). In this context of problematizations weaving around memory, experience and agency in the constitution of autobiographical subjectivities, I argue that the genealogical project of deconstructing rather than reconstructing the past becomes extremely relevant as a plane of analysis for feminist theorizations of the female subject. In this project of deconstruction, I have highlighted the catalytic role of gender in experimenting with how the technologies of the self can be bended (Probyn, 1993) and the technologies of autobiography can be interrupted (Gilmore, 1994). This privileging of gender is not a natural or psychological trait of some inherent essentialist dynamic; it is, rather, an effect of an active interaction between and amongst technologies of the self, technologies of gender and technologies of autobiography, which have 
allowed for new discursive regimes and planes of thinking to emerge. As Gilmore explains, 'interruption is a discursive effect of gender politics and self-representation and evidences the possibilities of and limitations on women's self-representation' (1994, p. 49).

In making my argument about the role of women's self-writings, as technologies of the female self, I have drawn on influential feminist analyses of women's strategies for writing the self. These analyses have explored the historical devaluation of women's writings that have both constrained their writing practices and have excluded them from the canon of traditional autobiographical texts. These analyses have further shown how, moving beyond silence, women began making sense of dispersed moments of their existence, and through writing they attempted to describe those moments and articulate them in a narrative system. I have been particularly interested in Stanton's (1987) theorization of women's autobiographies, memoirs, letters and diaries as practices of self-formation, the argument that the female self constitutes herself through writing. What has been particularly fascinating in the investigation of women's strategies for writing the self is that the female writers/practitioners of self-technologies interrogate their own authorship in a playful manner within a wider context of ambivalence surrounding their existence and self-assertion as authors of their own lives. Playfulness here is very much in line with Maria Lugones' theorization of play as an activity surrounded by uncertainty and open to surprise, 'to selfconstruction or reconstruction and to construction or reconstruction of the "worlds" we inhabit playfully' (Lugones, 1990, p. 401). Entering the male world of higher education and the newly opened professions, the women teachers of this study can indeed be seen as 'world travellers' as they travel across different worlds, adopting playful strategies that help them to survive the multifarious ways in which they are reconstituted as subjects. From this perspective of playfulness women writers 'are not done' with the author issue. They cannot be declared dead; they are 'alive', but they seem always to evade. The selves that are inscribed in their autobiographical texts lack the sense of organic integrity and question the principle of authorial intention that characterizes the male canon of the genre. It is this elusive condition of their textual existence that renders female autobiographical texts a challenging archive for the genealogist of technologies of the female self.

In this context, I have identified Foucault's work as carrying out a twofold functioning: first, his genealogies as alternative methods for social and historical research have opened paths that could lead to those selves hidden in 'little dramas, unimportant events, unpromising places' 
(Hacking, 1991, p. 28), the female selves, and second, his technologies of the self have sketched lines of analysis that, as Probyn has suggested, can be bent towards sexed/female selves: 'I think that in taking up Foucault's turn to the technologies of self we may find other perspectives on theoretical levels at which we can sex the self' (1993, p. 116). In rethinking the discursive analytical triangle delineated by the technologies of the self (Foucault, 1988a), technologies of gender (de Lauretis, 1987) and technologies of autobiography (Gilmore, 1994), what has been highlighted is the catalytic role of gender in decisively bending the Foucauldian technologies of the self (Probyn, 1993) and as radically interrupting the technologies of autobiography. This 'unruliness' of gender has not been attributed to some inherent essentialist force; it has emerged as an effect of an intense battle that has been staged on the discursive regime that these three sets of technologies have opened up. Seen as a discursive regime for the construction of the self, women's auto/biographical writings open up an interesting field for genealogical explorations. However, writing feminist genealogies which draw on women's autobiographical practices is an area relatively unexplored in research. It is to mapping this quasi-desert area that I will now turn.

\section{Mapping the genealogical domain}

while the historical self may be the autobiographer's explicit subject the story of her life with self-development as the structure of the text - this subject is distributed across the historical self and the textual self, both of which are versions of the self who writes. (Gilmore, 1994, p. 85)

Following the Foucauldian line, my analysis is set in a specific historical and cultural context; otherwise it would run the danger of the totalizations of the 'grand narratives' it is supposed to challenge. I therefore open up historical inquiries by reading various 'self-writings' by women teachers in the late nineteenth and early twentieth centuries, the era of the mass involvement of women in education. Being a period of crises and significant changes in the education of women not only in the UK, but also in Europe, America and Australia, I thought that the end of the nineteenth century perfectly constituted what Foucault has defined as emergence in the genealogical analysis. The turn of the nineteenth century as the moment of women's mass involvement in education has, of course, been the object of numerous and important historical studies, that have often attempted to find a place for it in a supposedly 
linear historical development of women's liberation. ${ }^{16}$ However, in the genealogical analysis, this linear development towards progress has been interrogated and problematized. In paying attention to the 'minor' pathways and processes surrounding the historical highway that has supposedly led women to the public sphere, different story-lines were able to emerge, while dissonances have often disrupted the melody of history. In focusing on the context of the fin-de-siècle era, I did not try to recover the woman teacher as a heroic figure of social history. I attempted an analysis of the specification of her emergence in a nexus of signifying genealogical events.

I have already indicated that my particular focus on genealogizing the female self in education relates to my own autobiography, my lived experiences as a woman teacher, but it certainly goes beyond the limits of the personal. I have seen education as a hot area of genealogical research, an arena of antagonistic discourses, a site of power from which women have been traditionally excluded. A whole web of discourses, special knowledges, analyses, legal and institutional arrangements, have settled upon this historical exclusion. Education, however, has been also the locus where counter-discourses and counter-practices emerged, to oppose the truth regimes and social structures that had legitimated and perpetuated women's exclusion. In the History of Sexuality, Foucault defines power as dependent on resistance: 'Where there is power, there is a resistance, and yet, or rather consequently, this resistance is never in a position of exteriority, in relation to power' (1990a, p. 95). I have therefore started from the recognition that women in education, striving for freedom, real-and-imagined, formulate a grid of analysis for genealogical research, a genealogical dispositif in Foucault's terms. Deleuze has described the dispositif as 'a tangle, a multilinear ensemble' (1992b, p. 159), composed of lines and zones that are difficult to determine and localize. These lines are usually deployed in unforeseen directions, while it is amidst crises that new lines are created, and new directions open (1992b, p. 160). Education can therefore be charted as a crisis-shaken area, par excellence, a 'multilinear ensemble' on the grounds of which 'unknown landscapes' emerge, while thinking evolves along moving lines. The dispositif of education, in particular, has indeed created regimes of exemplary visibility as well as regimes of shadow and darkness. What I suggest is that women seeking freedom through and within education have decisively shaken the order of visibility; they have been actively engaged in a continuous process of reinventing themselves and have dared to ask for more than 'the promise of a dream' (Rowbotham, 2000). 
What is particularly significant for a genealogy, as 'the history of the present', is the complexity of women's positioning in education today. Thus, in an attempt to formulate an attitude, 'a mode of relating to contemporary reality' (Foucault in Probyn, 1993, p. 109), I have also looked into contemporary autobiographical texts of women in education. It seems that as we have already passed the threshold of the millennium, women feel trapped in their 'conquests': 'I didn't know what was happening to me. My body died during those years... I was very tired, bone-achingly tired all the time... Children make you retreat behind the glass...' (Steedman, 1992, p. 61). Education is a site where juxtaposing discourses are framing women's lives, but still a theatre of local struggles and resistance, a transitional space in these lives.

I have argued that contemporary problematics in the living and working experiences of women educators give the analyst a grid of analysis for genealogical research. But how does this relate to self-explorations? Educating others involves contemplating techniques of self-formation, technologies of the self. As Foucault puts it, 'they [techniques of the self] are frequently linked to the techniques for the direction of others. For example, if we take educational institutions, we realize that one is managing others and teaching them to manage themselves' (1986b, pp. 369-70). Following Foucauldian and Deleuzian lines, what I therefore suggest is that education can be seen as a site for self-transformation, opening up opportunities for the recreation of pedagogy as a process that motivates and inspires the subjects that are involved in it to live a better life. Through their involvement in education women have been empowered to 'speak of themselves' and encouraged to explore other 'modes of being a woman'. In their attempt to 'fashion a self' they have often 'tried out' a plurality of selfhoods, which have sometimes left traces behind them.

In the process of my inquiries, I have often wondered where I should look for those traces, those 'grey meticulous details', the forgotten documents that genealogy is after. My explorations took me to the archives: reading forgotten women's diaries, letters, autobiographies and memoirs has offered me invaluable experience of genealogical research. Through my readings of women's autobiographical writings I have begun to make sense of how 'through autobiographical writing the self is written out of and into its historical context' (Steedman, 1992, p. 14) and how this very practice of writing is interwoven in a critical technology of the self.

Using women's autobiographical texts to deploy my genealogical analysis has been a methodological decision that came to me almost naturally. This 'naturalness', however, was not created out of the blue. 
It is related both to the Foucauldian frame of my work as well as to recent feminist theorization of autobiographies not only as a literary genre, but most importantly in connection to the impact of the use of autobiographies in historical and sociological analyses of the female subjectivity.

As the first quotation of this chapter indicates, Foucault was quite explicit about the autobiographical elements of his theoretical work. In addressing epistemological problems related to the validity of knowledge that derives from personal experience and/or life stories, Morwenna Griffiths argues that 'autobiographical material is a good source of knowledge' (1995, p. 13). Thus, drawing on a range of theoretical and political discussions about the uses of autobiographical material, I have explored women teachers' self-writings first as an area of genealogical research and second as a set of technologies of the self.

\section{Textual selves of grey documents}

Following genealogical trails, I have worked with fragmented and scattered autobiographical pieces, being attentive to a system of moments, rather than coherent narratives of 'complete lives'. As Quinby (1991, p. 137) has argued, these moments of being ${ }^{17}$ reveal 'the incoherences, confusions, contradictions and gaps constituting any selfhood'. In specifying the historical and social conditions within which the female selves unfolded, I then worked to situate my fragmented 'findings' within a landscape, a cinema plateau that can serve as 'a view from somewhere' (Haraway, 1991, p. 196). It was like shooting a film of different happenings with a common theme. In the case of women teachers' selfwritings, it was slightly more complicated, since there were several themes intertwined together. What I was trying to do was to 'deal with a rhythm in a system of moments' (Humm, 1989, p. 45). In working simultaneously with multilevelled differences, I have tried to experiment with a sort of 'rhythm analysis', ${ }^{18}$ since, as Henri Lefevre has put it: 'what we live are rhythms - rhythms experienced subjectively' (1991, p. 206).

Exploring such systems of moments, my genealogical inquiries look into autobiographical writings of women teachers in the late nineteenth and early twentieth centuries, and particularly from 1860 to 1914. This period has already proved of particular interest for the historians of women's education. It is a period that signalled major changes in the education of women. As Purvis (1991), has noted, there were various reasons for these changes, particularly the evolution of a state system of mass elementary schooling, which resulted in women's participation in the teaching profession. According to Pendersen (1991), it was also a period that created a new category of female teacher, the public school 
headmistress. Distancing themselves from a tradition that educated the girls of the middle classes for a private, leisured role, the public school headmistresses valued academic achievement and aspired to educate middle-class girls for a public role.

Feminist scholars have produced influential socio-historical analyses relating to these developments. ${ }^{19}$ Pedersen, however, has argued that there is a need for further investigation into the ways that the reforms made in women's secondary education and the movement for the higher education of women influenced women's entry into public life and encouraged them to attempt roles beyond the private sphere (1991, p. 56). Alison Prentice and Marjorie Theobald have further posed the problem of the need for the rewriting of the history/ies of women teachers. They have pointed out unexplored paths for future feminist research, in particular, stressing the need for further analysis of the personal lives of women teachers, as well as of their practices of resistance (1991, p. 25). Prentice and Theobald (1991, p. 14) have also underlined historians' recent interest in personal narratives, which can create a different 'history', drawing on the diversity of experiences of women teachers themselves. In the context of such problematics, I suggest that British women teachers' autobiographical writings of the late nineteenth and early twentieth centuries, have recorded a whole series of micro events as well as micro discourses, dealing with diverse ideological, political and personal issues.

Drawing on a variety of autobiographical and biographical sources, I have focused on the textual lives of female teachers in a range of social and cultural contexts, at the turn of the nineteenth century. College women, first as students and later as teachers, were amongst the first I have examined and this was the case of the Girtonians Louisa Lumsden and Constance Maynard and the Newnhamite Anne Jemima Clough. The writings of these three women reflect aspects of the self-technologies developed by women teachers who studied and/or taught in the colleges associated to the University of Cambridge and became influential figures in the evolution of university colleges for women. Their lifewritings also represent typical cases from the above mentioned movement for the higher education for women, a movement directly associated with the education of women of the middle classes.

Middle-class women striving for better educational opportunities, had to fight against a whole set of institutions, practices, discourses and curricula that aimed at turning girls into housewives. They also had to fight against all sorts of restrictions that prevented women from having access to any level or type of higher education, a necessary 
condition to enter the professions or simply develop a creative mind and enhance themselves through knowledge. The establishment of university-associated women's colleges, a movement initiated in 1869 with the opening of a college at Hitchin which was later to move nearer Cambridge and become Girton College, was a major step towards the

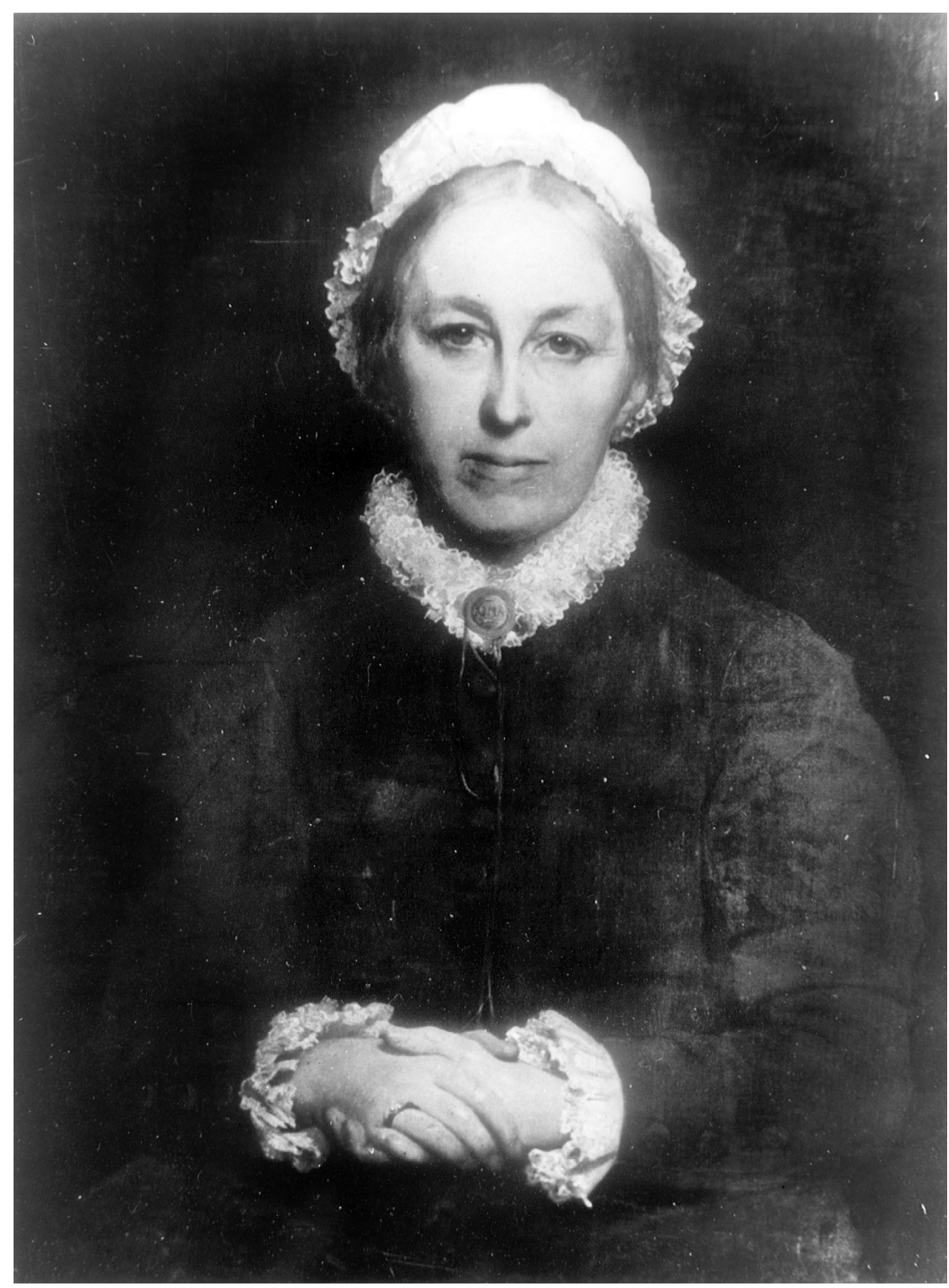

Illustration 1 Emily Davies, founder of Girton College 
opening of universities to women (see Illustration 1). It was very soon followed by the founding of Newnham College.

The existence of two women's colleges in Cambridge institutionalized the already existing differences with regard to the higher education for women. Since the movement for the higher education of women was a very strong counter-discourse of the era, it is not surprising that it provoked opposing and contradictory ideas and arguments, concerning its practical applications. As is known and has been widely analysed, there were two main ideological directions with regard to the best way of leading women to higher education, 'the uncompromising and the separatists' as Sara Delamont calls them (1978a, p. 154). The former claimed that women's colleges should follow exactly the same procedures and regulations with the traditional university colleges for men, while the latter argued that the particularity of being a woman and having a background of a differently oriented education, should allow for certain exceptions and more lenient regulations. What both directions and their followers shared, however, was their being bound to what has also been described by Delamont (1978a, p. 160) as 'double conformity', that is a preoccupation with the standards of lady-like behaviour on the one hand and the aims and values of the male educational system on the other. ${ }^{20}$

Louisa Lumsden (1840-1935) came from Scotland and was one of the five Girton pioneers (see Illustration 2). She went for the classic tripos and later became a tutor at Girton, then at Cheltenham Ladies' College and finally headmistress of St Leonard's Public School for Girls. While at Girton, Louisa Lumsden met Constance Maynard (1849-1935), who came to the College in 1871, and they became friends. Constance came from a strict Evangelical family and had to overcome many difficulties, before she was allowed to sit the examinations for entering the college. She later founded Westfield College. She was a prolific writer and produced volumes of diaries, an autobiography and books drawing on autobiographical aspects of her life, the most well-known being 'Between College Terms'. Her writings remain unpublished in the archives of the library of Queen Mary and Westfield College (see Illustration 3).

Anne Jemima Clough (1820-92) came from a previous generation. From her youth, she had had to work as a teacher to compensate for the loss of the family fortune after her father's death. As a secretary of the North of England Council, she put forward the argument that women needed a different type of examination as a result of their separate and different education and secured the admission of women to Manchester and Newcastle colleges. In 1871 she took charge of what was to become Newnham College in Cambridge, and it was from 


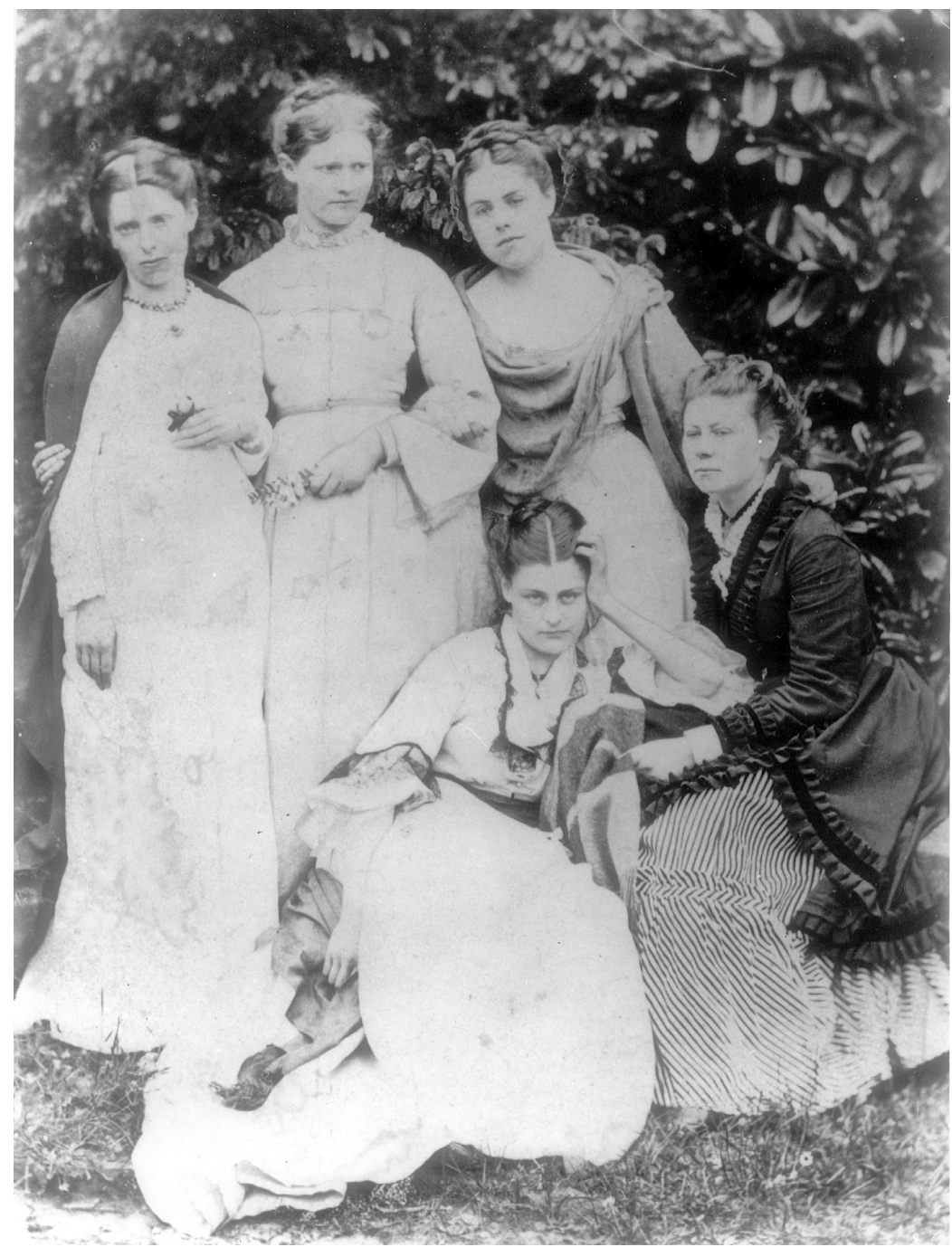

Illustration 2 1869, the five Girton pioneers from the left: I. F. V. Townshend, S. Woodhead, E. C. Gibson, L. Lumsden, sitting on the right, R. S. Cook in the middle

that position that she developed her own strategies with regard to the higher education of women.

Girton and Newnham had various institutional and organizational problems, but they were prestigious compared to the sometimes dreadful 


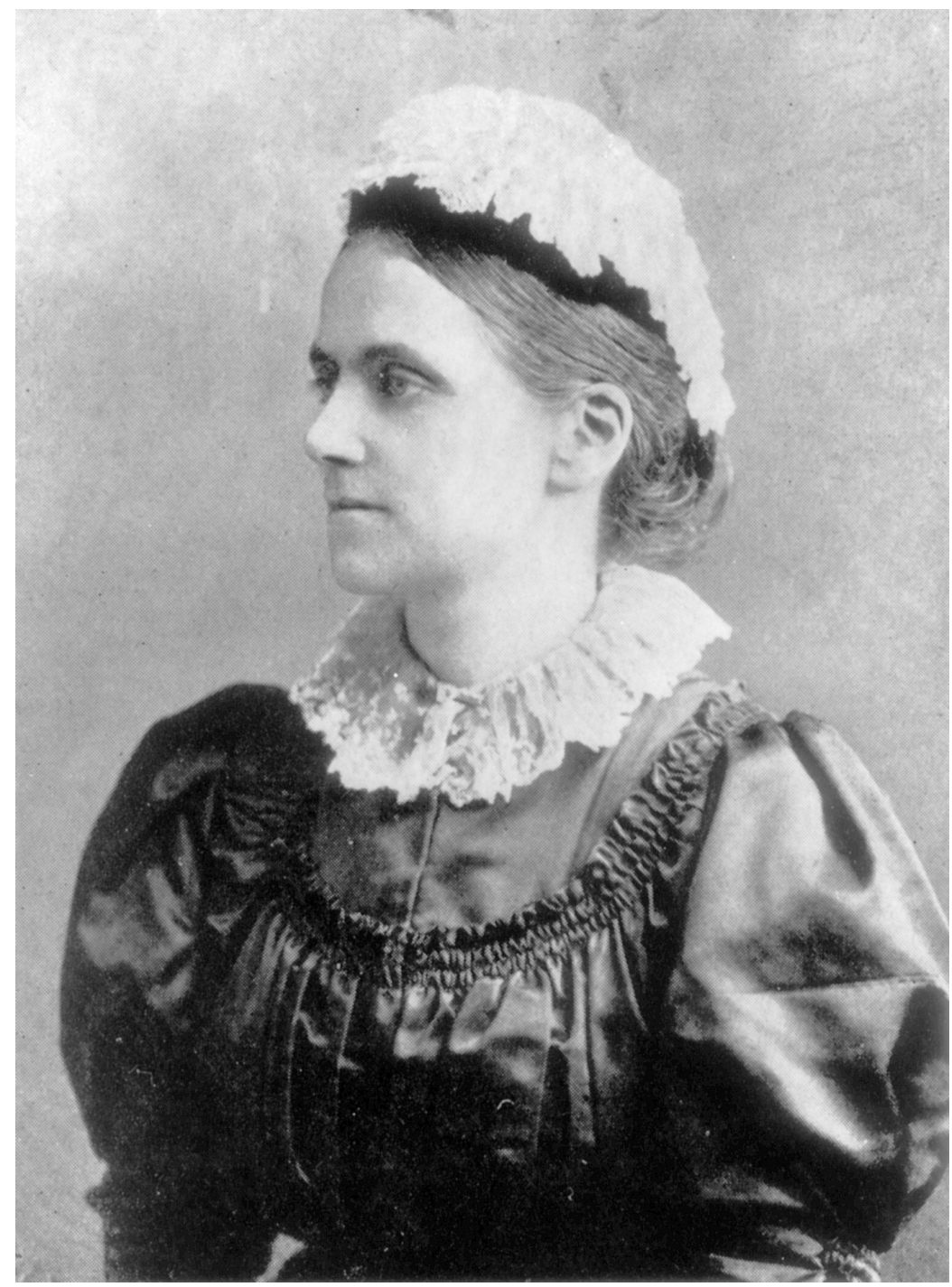

Illustration 3 Constance Maynard. A heroic pioneer or a grey figure?

conditions of the teacher training colleges. ${ }^{21}$ It was in this light that I have read autobiographical writings of Winifred Mercier (1878-1934). She spent some of the best years of her life looking after her ill mother. While working as a teacher, she also studied for her external London 
degree. Mercier became a pioneer in the reform of teacher training colleges and later in her life a Girton College don. Her correspondence with her friend and fellow teacher, Jean Borland, offers a view of suffocated feelings and a longing for new intellectual and bodily experiences.

Excavating technologies of the self cultivated in spaces where women lived, worked and were educated collectively, I have further considered the self-writings of women who became known for their contribution to the development of girls' secondary education, a sector that was developed either in girls' public boarding schools or in daily high schools for girls. ${ }^{22}$ I refer in particular to Dorothea Beale (1831-1906), headmistress of Cheltenham Ladies' College, and Mary Frances Buss (1827-94), founder and first head of North London Collegiate School and Camden High School for girls. As principal of Cheltenham Ladies' College, Beale founded St Hilda's College, Cheltenham, as the first English training college for women and she also sponsored St Hilda's Hall in Oxford for women teachers. As has been commented, Buss managed to bridge the gap between the mentality of the private schoolmistress and the newly emerged persona of the public headmistress; she was actually the first woman to call herself a headmistress (Pedersen, 1991, p. 45). 'Miss Beale' and 'Miss Buss' were among the few women teachers who achieved renown as individuals and they have, consequently, been the subjects of several biographies. ${ }^{23}$ However, retelling well-known stories in order to destabilize their myths has been a crucial point of revision in the history of feminist thought and it is from this perspective that I have reread the stories of 'Miss Beale' and 'Miss Buss'.

Although girls' secondary education was to some extent influenced by the divisions between the 'separatists' and the 'uncompromising', there is also a striking continuity in the way women organized their life and work in the newly established educational institutions. What women's auto/biographical writings convey most strongly is a matrix of ethical concerns, aesthetic orientations and social attitudes which links them to the new emerging female culture of the university colleges. Such links were most of the time 'real' and practical rather than ideological, since the majority of the colleges' graduates would become teachers of secondary schools, while the pupils of the secondary schools would become students of the colleges. ${ }^{24}$

In the history of women's education there is also the case of assistant schoolmistresses, women teachers who worked in the secondary sector, after having themselves completed a type of secondary education available for the daughters of the middle class. This is the case of the diary of Clara Collet, 'The diary of a Young Assistant Mistress'. Clara Collet 
(1860-1948) was a student at the North London Collegiate School. At the age of 17 she left London to become an assistant schoolmistress in a girls' high school in Leicester. While teaching there, she studied for both an external London BA and a teaching qualification. She later left teaching to study for an MA in Moral and Political Philosophy at University College London and became a social researcher. As has been commented elsewhere, like their male colleagues, many women teachers used teaching 'as a stepping stone to more powerful professional or political roles' (Prentice and Theobald, 1991, p. 15). Collet's seven-year diary (1878 to 1885) clearly reflects the beliefs, hopes and aspirations of those women who used teaching as a lever to other professions. It is a diary which does not reflect the culture of college life. Its context is the real world of teaching, where women were developing techniques of themselves within a professional life, a situation about which they felt most uncertain, and which created contradictory feelings and attitudes. ${ }^{25}$

Since issues of gender always ride on issues of class, my readings have included auto/biographical writings of women teachers of the lower strata, teachers very often living on the edges of poverty. This is the case, for example, with the autobiography of Molly Hughes, born in 1866. She came from a family from the lower middle class, attended the North London Collegiate School and trained as a teacher in Cambridge. Molly's autobiography follows her adventures in several educational institutions both as a pupil and teacher. Her autobiography reflects her admiration for 'real colleges', like Girton, as well as her joy at her life in the training college, where she could be on her own for the first time. More difficult in terms of financial and social possibilities was, however, the case of Helen Corke (1882-1978) from South London. She was a friend of D. H. Lawrence and came into teaching through the pupilteacher system. ${ }^{26}$ Although these self-writings emerged from working experiences in the hard and cruel world of elementary schools, they reflect personal wishes and aspirations in common with the women teachers of the upper strata as well. While going out and around London, Corke resents her poverty as well as 'the happiness' of her married cousin and dreams of a spiritual life and freedom 'that must be followed' (1975, p. 148).

As Prentice and Theobald have suggested, 'women teaching in domestic settings and those who owned their own schools have been the least visible in the historiography of education' (1991, p. 9). Attempting to throw light onto this dark side of female teachers' history, I finally refer to Mary Smith, the only case of a working-class teacher whose life is read in this study. Mary Smith (1822-89) came from Oxfordshire. 
As Mary Smith declares at the very beginning of her autobiography, 'I was born in an English nonconformist household, of simple country habits, of the order of common people, without any pretension whatever to wealth or rank' $(1892$, p. 1). When she was about 18 , she left her father's home and went to the north of the country, following the Osborns, a family with whom she developed a strange love/hate relationship. It was in the north that she became a self-taught teacher, sometimes working on her own and at other times with the Osborns or as a governess. She finally established her own school in Carlisle, where she lived till the end of her life. She was also involved in journalism and wrote poetry. Her poems have been published as the second volume of her autobiography, Miscellaneous Poems of Mary Smith (1892). Her autobiography documents the harshness of life and work of rural schoolteachers, but in a remarkable way it depicts her passion for an intellectual life, beyond conformist patterns of behaviour and rigid class constraints.

Although the self-writings I have referred to were produced within distinct social, financial and cultural conditions, this study will not focus on the traditional division between working-class and middleclass women teachers. I think that feminist historians have already both explored and problematized the impact of social class on the education of women. ${ }^{27}$ Instead, my inquiries look specifically into variations emerging from the social and personal spaces within which women teachers' lives unfolded. A decisive - but not exclusive - factor for these autobiographical writings is the space/s of their production, an idea that will be further expanded in the following chapter. Yet what they reveal as a whole is an extraordinary common area of ideas, feelings and attitudes that seem to transgress social boundaries in their attempt to open up new directions in women's lives.

What about 'this present of ours', however? How has it been 'documented'? I have already referred to the difficulties of facing the present, to stabilize what is continually moving and changing and reflect upon it. Thus, rather than 'document our present', what I have tried to do was to freeze some fragmented 'moments of being' and in Virginia's Woolf's idea, build some narratives from fragments of meaning in order to understand other narrative fragments of meaning (Erben, 1993, p. 18). In this I have certainly made certain choices. I have listened to some voices, while being aware of the epistemological problems such a selection, inevitably, raises. As Griffiths has clearly put it: 'which few others do I choose from the very large number I could listen to, since it is plainly impossible to undertake such a serious project with every human 
being. That is, who should I listen to?' (1995, p. 45). In agreement with Griffiths that this is indeed a difficult question, I have drawn again on the Foucauldian framework of my genealogy to make clear that the voices I have chosen to listen to are voices of dissonance. They tell stories of women teachers who feel uncomfortable about their life, who do not hesitate to confess their dilemmas and reveal the dark side of their self. They are women who have interrogated their way of being in the world, without having any alternative life pattern to follow. Perhaps their insistence on change is the only line that keeps them within the cartography of female subjectivity, this genealogy has attempted to draw. This is how I have read their/our stories.

Carolyn Steedman (1992) hated her life as a teacher. Perhaps because she loved it too much in the first place and couldn't protect herself from 'burning'. She has told fascinating stories of how it feels to be a teacher who can no longer bear the children she once loved and became passionately attached to. Her voice from within the 'prisonhouses' has broken the silence, the taboo of speaking out women's discontent of being with children, either as mother, or teacher or both. In reading Valerie Walkerdine's (1990) stories, I have recognized my own schoolgirl fictions that have constrained my becoming an adult of this world. She has depicted shocking pictures of women teachers struggling with unresolved dilemmas and incompatible contradictions. Unlike her great aunt, Clara Collet, Jane Miller (1996) never stopped loving teaching, perhaps because 'her children' were somewhat older and she did not have to 'mother' them so much. She tells stories of those women teachers - and they are many - who have seen teaching as a way to change the world, or at least do something about it.

'Holding On' was a group of women teachers that was formed at the end of an MA in Urban Education course. We came from different sectors of education, had different life patterns, different stories and even countries behind us. The group kept us together for almost two years, 1992-94. During this period we had meetings, followed by social outings, discussed our readings of books and papers, wrote a paper in collaboration, which we presented at a St Hilda's conference in 1993, and we kept a diary for the same day and then for the same week, to share our experiences, 'all the horrors, joys and pains of working/living/ just coping' (Holding On, 1993). Some of the themes of our discussions, readings and writings addressed the ways in which our autobiographies informed our theoretical concerns and our research projects, the experience of collective feminist writing, older women in education, friendships and communities of choice. 
I have read many stories, and I have even written my own part of a story. As Foucault sees it, genealogy involves searching meticulously in the most unpromising places, reading and re-reading dusty documents, paying attention to unimportant details, trying to discern unheard voices. In reading these stories, however, I have come to admit that women's auto/biographical writings, in spite of their spontaneity, already include processes of selection, through which some moments 'have been remembered' and written about and some others have not. Reflecting on Virginia Woolf's moments of being, Liz Stanley (1992) has theorized the relationship between the present and the past self, the present and the past being conceptualized as two 'platforms' on which the auto/ biographer ${ }^{28}$ is trying to locate the self. When it comes to the exploration of the past Stanley suggests that memory acts selectively and it is therefore very probable that a 'lie' or an untold truth can hold more truth than the presented 'truth'. Stanley argues that there is no 'knowledgeable past'. The 'facts' are a product of their time, place, author as well as of their reader. In this context, she sees auto/biographies as ideological products rather than representations of an objective truth, which in itself is considered as an ideological product. Thus, the genealogical exploration of female teachers' fragmented documents of lives has created a secondary layer of moments, already taken out of different primary selections made by the authors. My task as a genealogist has been to recognize my 'perspectival seeing' and replace the quest for 'objectivity' with 'a view from somewhere'. This strategy of situating the 'findings' within a context of certain political, cultural and historical practices draws, as we have seen, on Haraway's postmodern feminist project, which calls into question the ideal of epistemic purity and its supposed independence from politics: 'I would like a doctrine of embodied objectivity that accommodates paradoxical and critical feminist science projects: feminist objectivity means quite simply situated knowledges' (Haraway, 1991, p. 188). In this context women's autobiographical writings, while emerging from the dark sphere of humanity and speaking from the underground terrain of subjugated knowledges, are not exempt from critical re-reading and deconstruction. Like Scott, Haraway does not assign any sort of epistemic privilege to the subjugated standpoints of women and/or excluded 'others'. However, Haraway has suggested, that a postmodern feminist project can include the possibility of partial views being joined into collective subject positionings that promise a living within and beyond limits, shaping transitional spaces for the accommodation of the contradictions and juxtapositions in women's lives. It is, then, more than a theoretical reference that makes 
me end this chapter with the words of Donna Haraway, who has enabled me to see through, but at the same time beyond, partial and subjective histories:

The science question in feminism is about objectivity as positioned rationality. Its images are not the product of escape and transcendence of limits, i.e., the view from above, but the joining of partial views and halting voices into a collective subject position that promises a vision of the means of ongoing finite embodiment, of living within limits and contradictions. (Haraway, 1991, p. 196) 


\section{Index of Names}

Acker, Sandra, 142, 147

Althusser, Louis, 25, 26

Anzaldúa, Gloria, 181

Anderson, Linda, 7, 30

Ball, Stephen J., 136, 146, 147, 182,183

Bachelard, Gaston, 65, 78

Bartkowski, Frances, 69, 71

Beale, Dorothea, 46, 62, 162, 164, $167,169,170$

Bland, Lucy, 106, 107, 110, 111, 121,123

Borland, Jean, 46, 67, 182

Braidotti, Rosi, 1, 2, 17, 24, 27, 28, 33, 157, 158, 159, 160, 179, 181, 183

Brodzki, Bella, 32

Brontë, Charlotte, 73, 115, 116, 125

Burstyn, Joan, 182

Buss, Mary Frances, 46, 120, 129, 162, 164,182

Butler, Judith, 24, 26, 27, 28, 157, 179

Cavarero, Adrianna, 35, 133

Collet, Clara, 46, 47, 49, 52, 116, 117, $129,145,146,149,159,160,180$

Corke, Helen, 47, 53, 59, 69, 94, 113, $114,124,126,175$

Clough, Anne Jemima, 41, 43, 59, $65,66,72,83,85,86,98,114$, 117, 120, 162, 165, 175, 182

Colebrook, Claire, 180

Copelman, Dina, 64, 68, 98, 129, $149,176,180$

Davies, Emily, 42, 62, 64, 68, 82, 83, $89,98,100,117,165,171,180$

De Lauretis, Teresa, 6, 7, 22, 24, 25, $26,28,33,34,37,58,61,136,137$, $148,157,179$

Dean, Mitchell, 13, 179

Delamont, Sara, 43, 89, 101, 180, 181,182
Deleuze, Gilles, 15, 22, 28, 29, 35, $38,157,179,180$

Diamond, Irene, 24, 179

Dove, Frances, 131, 180

Dreyfus, Hubert L., 14, 18, 22, 179

Dumm, Thomas, L., 181

Duncan, Nancy, 78, 181

Dyhouse, Carol, 19, 105, 106, $180,181,182$

Flax, Jane, 179, 182

Gaskell, Elizabeth, 73, 115, 116

Gilmore, Leigh, 6, 29, 33, 34, 35, 36,37

Greenway, Judy, 107, 120

Gregory, Derek, 56, 57, 181

Grier, Linda, 67, 167, 168, 169, 175

Griffiths, Morwenna, 40, 48, 49, 152,160

Grumet, Madeline, 138

Guattari, Felix, 28, 29, 157, 180

Hamilton, Cicely, 111, 112, 182

Haraway, Donna, 27, 28, 40, 50, $51,157,181$

Holding On, 49, 134, 142, 143, $144,145,146,150,151$

hooks, bell, 60, 67, 151, 152, 181

Hughes, Christina, 182

Hughes, Molly, 47, 62, 63, 64, 65, $84,90,129,176$

Jelinek, Estelle, 32, 34

Kamm, Josephine, 62, 118, 120, 162 , $164,167,169,170,171,180$

Kant, Emmanuel, 8

Kaplan, Caren, 69, 70, 181

Kaplan, Cora, 180

Kean, Hilda, 52, 180, 182

Kritzman, Lawrence D., 179

Kundera, Milan, 101, 160, 181 
Lawrence, David H., 47, 114

Lefevre, Henri, 40, 54, 55, 56, 57, 181

Lloyd, Moya, 179

Lugones, Maria, 36, 70, 71, 181

Lumsden, Louisa, 41, 43, 44, 68, $72,76,83,87,90,92,95,96$, $126,127,129,130,180,182$

McDowell, Linda, 54, 55, 61, 70, 87, 181

McNay, Lois, 10, 20, 179, 183

McRobbie, Angela, 127, 128

Mackinnon, Alice, 104, 107, 117, 182

Mahon, Michael, 10, 13, 179

Marsden, Dora, 121

Massey, Doreen, 53, 54, 55, 56, 60, 61, 181

May, Todd, 179

Maynard, Constance, 41, 43, 53, 59, $62,68,80,83,84,85,86,87,88$, $90,92,94,98,100,118,119,123$, $124,125,126,127,128,129,130$, $131,148,149,158,162,166,171$, $175,181,182$

Maynard, Mary, 109

Mendus Susan, 125

Mercier, Winifred, 45, 46, 67, 166, 167, 168, 169

Miller, James, 11, 179

Miller, Jane, 49, 138, 147, 148, 150, 151,180

Mills, Sara, 23, 68

Morris, Meaghan, 70

Nicholson, Linda, 179

Nietzsche, Friedrich, 8, 10, 12, 13, $18,84,177,179$

Pedersen, Joyce S., 41, 46, 180

Perrault, Jean, 32

Plath, Sylvia, 103

Prentice, Alison, 41, 47

Probyn, Elspeth, 22, 28, 30, 35, 37, 39, 154, 179, 181

Purvis, June, 40, 180, 181

Quinby, Lee, 24, 40, 179

Rabinow, Peter, 14, 18, 22, 179

Raikes, Elizabeth, 180
Rajchman, John, 8, 13, 14, 22,

$75,135,137,179$

Ramazanoglou, Caroline, 179

Rasmussen, David, 179

Rendall, Jane, 125

Richardson, Dorothy, 141

Rose, Gillian, 54, 55, 56, 57, 59, $60,61,64,90,181,153$

Rowbotham, Sheila, 38, 181

Rubin, Gayle, 25, 179

Sawicki, Jana, 3, 14, 179

Schenk, Celeste, 32

Schmid, Wilhelm, 19, 21, 176, 177, 179

Scott, Joan, 23, 30, 50, 179

Simons, Jon, 18, 20, 101, 102, 179

Smith, Mary, 47, 48, 53, 69, 112,

$113,114,115,118,119,122$, $125,166,167$

Smith, Sidonie, 30, 31, 32, 33, 35, 180

Soja, Edward, 53, 54, 55, 56, 57, 58, 68, 181

Stanley, Liz, 50, 181

Stanton, Donna, 32, 33, 34, 36, 104

Steadman, Cecily, 65, 72, 89, 116, $172,173,180$

Steedman, Carolyn, 29, 30, 39, 49, 134, 136, 137, 138, 144

Stephen, Barbara, 62, 63, 64, 68, 82, $83,98,100,165,171,182$

Tamboukou, Maria, 180, 183

Thacker, Andrew, 20, 179

Theobald, Marjorie, 41, 47

Veyne, Paul, 12

Vicinus Martha, 62, 173, 180, 181,182

Walkerdine, Valerie, 49, 52, 103, 134, 147,150

Watson, Julia, 30, 31, 32, 33, 35, 180

Weedon, Chris, 24, 179

Widdowson, Frances, 81, 180, 181,182

Wolff, Janet, 69, 70, 181

Woolf, Virginia, 48, 50, 62, 76, 180,182

Young, Iris Marion, 59 


\section{Index of Subjects}

aesthetics, 19-21, 155, 174, 176-8

agency, 6, 12, 35

archaeology, 179

archive, 11, 31, 36, 39, 43, 68

asceticism, 17, 19

asylum, 11

attitude, 22, 39, 46-8, 60, 65, 70, 73, $112,115,124-5,144,146,155$, $160,172,175-6$

autobiographics, 33-4

autobiography, 1, 3-7, 25, 29-41, 43, $45-50,52,58,61-2,65,67-9$, $76,78-9,83,85-7,92,98,100$, $112,114,118,119,123-5,128-9$, $133,143,145,159,165-6$

auto/biography, 1, 37, 46-7, 50, 122 auto/biographical, 1, 29

autograph, 33

autography, 32-3

autographical subject, 33-4

autogynographies, 33

becoming, 1, 2, 5, 7, 13, 21, 26, 28, $31,105,136,153,157,178$

binarism, 33, 56, 75

bio-politics, 24, 107-8, 139

bio-power, 66, 108

carceral systems, 9

cartography, 2, 5, 24, 25, 34, 49, 65, $66,75,87,151,153,171$

classification, 14, 21

conditions of possibility, 30, 34

conduct, 15-17, 74, 98, 105

confession, 23

confinement, 58-9, 104, 166

demands of style, $20-1$

desire, 29, 52, 58, 59, 64, 67, 68, 73, 74, 85, 94, 103, 104, 107, $108,111,115,120,123-4$, $128,150,160,162$

deterritorialization, 34 diagram, 19

diaries, 3, 30, 36, 39, 43, 46-7, 49,

$68,117,142,149$

discipline, 9, 19, 85, 100, 102, 115, 166,171

discontinuities, 9, 10, 52, 66, 80, $82,137,138$

discourses, 1, 4, 5, 8, 19, 21, 25, 31, $33-4,38,41,55,57,60,71,79$, $95,102,103,115,129,132$, 135-6, 138-40, 142, 146-7, $153-4,157,158$

antagonistic discourses, 38, 78, 140

contradictory discourses, 133, 139

counter discourses, 34, 38, 43, 55, $71,164,173$

fictional discourses, 8

hegemonic discourses, 7, 26, 34, 58,151

institutional discourses, 26

juxtaposing discourses, 39, 104

medico-scientific discourses, 23 , 105, 106

micro discourses, 41

nationalist discourses, 60

popular discourses, 76

radical discourses, 101

reverse discourses, 34, 107, 109, 136

scientific discourses, 139

spinster discourses, 106

war of discourses, 9, 104, 140

discourses of care, 121, 151

discourses of frigidity and

passionlessness, 25

discourses of love, 118

discourses of marriage, 121

discourses of prudery, 109

discourses of representation, 6

discourses of school management, 147

discourses of sexuality, 2, 22, 23, 103,

$105,106,108,121$

discourses of travel, 70

discourses of womanhood, 82 
discourse theory, 24

discursive acts, 27

discursive areas, 105

discursive conditions, 33

discursive constraints, 90, 133

discursive constructs, 30, 75

discursive context, 105

discursive effect, 36, 56

discursive escape, 59

discursive formations, $34,61,81$, 104, 135, 140

discursive positions, 25,26

discursive practices, $8,10,24,135$

discursive regime, $8,32,34,36,37$

discursive relations, 24

discursive separation, 126

discursive struggle, 78

discursive systems, 34

discursive texts, 30

discursive triangle, 7, 29, 33, 37

discursive ways, 53, 96

dispositif, 5, 18-19, 38-9, 135, 151

enlightenment, 2, 8, 13, 17

entrapment, 59

episode, 9, 13, 138

epistemological 14, 17, 25, 27, 28, $40,48,50,57,103$

escape, 4, 51, 59, 72, 94, 111-12, 115,128

estrangement, 34, 59, 66

ethical substance, 16-17

ethics, 1, 5, 15-17, 20-1, 114, 131, $133,155,167-8,171,174$, 176-8, 182

eventalization, 10, 151, 174

experience, $2-3,6,20,30,32-5$,

$38-41,46-7,49,53,55,58-9,61$, 66, 69-71, 73-4, 78-9, 83-4, 90, 100-1, 119, 123, 125, 128-30, $133,135-6,138,140,143,146$, $150-2,156-9,165-6,176-8$

feminism, 7, 23-4, 27-8, 32, 104-12, $118,121,123,136,140-1,144$, $151,156,160,174-5$

critical feminisms, 7, 22, 24, 27, $29,33,50,108$

moralist feminism, 106 feminist critical pedagogy, 152

feminist film theory, 26

feminist genealogies, 6, 29, 37

feminist geographers, 57

feminist histories, 31, 48

feminist politics, 27, 157

feminist spatial analyses, 57, 61, $67,69-71$

feminist subject, 26,160

feminist theory, $2,4,5,6,12,18,22$, 24-5, 27-33, 35-6, 40-1, 46, 50-1, 56-7, 59-60, 133, 136, $140,151,156-8,177$

freedom, 3, 8, 9, 13, 38, 47, 53, 55, $59,64,67-9,71,80,100-1$, $109,111,121,131,144,148-9$, $171,174-7$

friendship, 24, 49, 76, 117, 130-3, 164,173

genealogy, 1-5, 7-22, 24, 29-32, 34-7, 104-5, 131-2, 137-8, 155, $174,178-9$

genealogy and counter-memory, 9 genealogy and self-writing, 40, 48, $50,76,122$

as critique, 12

as effective history, 13

as grey, 10

as history of the present, 8,39 , 134-5

as ontology of the present, 13

as resistance, 3

as the analysis of descent and emergence, 12-13, 132

as the philosophy of the event, 9, $10,13,138,151,174$

genealogical axes, 17, 31

see also feminist genealogies genealogical historiography, 10-11 genealogical strategies, 2, 4,

9-10, 14-19, 29-31, 34,

36-7, 39, 48-50, 53, 56-7, 71,

74, 81-2, 101, 109, 129, 135,

137-8, 151, 156-7, 171,

174-5, 177

gender, 22-3, 56, 60, 76, 90, 142

construction of, $7,25-7$

ideology of, 25, 89 
and class, 47

and place, 54, 61

and race, 142

and space, 57, 71, 142

and sexual difference, 27

and self-writing, 31-6

and technologies of the self, 154

as self-representation, 6, 25-6

as social representation, 6, 25-6

gender blindness, 4

gender difference, 18

gendered identity, 3, 57, 60

gender performativity, 27, 168

gender politics, 36

gendered power relations, 4, 55-6, 120,171

gender relations, 57, 66, 111, 141, 151,153

gendered spaces, 57

gendered subjectivities, 56

governmentality, 19

hermeneuticism, 10

heterotopias, 4, 52, 61, 75, 78-82, 101-2

human sciences, 12

humanism, 14

humanist geographers, 55, 57, 64

identity, 2, 27, 31, 34, 60-1, 69, $71,73-4,121,135,160$

ideology, 6, 12, 25-6, 70, 102, 106, $140,142,173$

individual, 6, 9, 25-6, 46, 80, 104, $135,144,146-7,152$

as object, $15,16,115$

as subject, 15, 19, 20, 155, 175, 176,177

institutions, $3,6,19,23,38,39,41$, $43-4,46-7,58,60,72,79,81$, $96,101-2,106,135,136,144$, $147,149,151,160$

and discipline, 96, 132, 146

and truth, 139

as greedy, 146

of marriage, 120-1

institutional restraints, 133

interpretation, $16,23,28,30,35$, 55,68 knowledge, 8, 15, 38, 40, 42, 72, 74, $83,86,125,126,148,152,157$, $158,171,172,174$

situated knowledges, 27, 50, 157

subjects of, $15,28,156$

subjugated knowledges, 35, 50, 157

types of, 19

validity of, 40

will to knowledge, 150

knowledge and power, 57, 58, 66, 76, 78,135

and truth, 8, 155

as perspective, 18

of details, 11

of struggles, 4

of the self, 74, 154, 155-6, 174

letters, 3, 30, 36, 39, 67, 115-16,

$124,156,166,169-71$

map, 4, 11, 15, 16, 23, 24, 28, 29, $31,32,37,56,58,61,74,78$,

$81,82,87,102,135,151$

memoirs, 30, 36, 39

memory, 35, 50, 127, 128

see also genealogy and counter-memory

micropolitical, 6, 7, 26

mode of subjection, 17

moments of being, 40, 48, 50, 58, 156

moral agents, 15

codes, 124

commitments, 140

conduct, 17

domain, 177

norms, 11

obligation, 17

orientation, 140

principles, 171

thought, 158

morality, 111, 114, 168

see also sexual morality

multiplicity, 2, 54-7, 70, 75, 104, $123,133,156$

narratives, 3, 7, 10, 29, 40, 48, 58, $65,67,123,128$

autobiographical, 7, 35, 69, 118, 128,129 
narratives - continued

dance, 129

grand, 37

master, 35

of truth and experience, 33

personal, 41, 112

textual, 4

narrative exchange, 133

narrative system, 36

nexus, $1,4,5,19,38,54,61$

nomads, 5, 157, 178, 183

nomadic consciousness, 157

nomadic shifts, 157

nomadic subjects, 28,157

nomadism, 28, 157

norms, 11, 177

cultural, 128

normative category, 13

normalization, 17, 106

objectification, 16,60

paradox, 2, 5, 23, 64, 96, 101, 109, $113,156,166$

paradox of being a woman teacher, $136-7,145,147,148,150-3$, 153,157

passions, 48, 59, 72, 78, 107, 115, $118,122,123-6,129,131-2$, $149,151,153,158,160,175-6$

pedagogy, 4, 15, 39, 148, 151

caring, 141, 151

see also feminist critical pedagogy

personal/political, 1, 24, 84, 144, $152,175,178$

perspective, $5,18,30,36-7,46,56$, $60,66,69,74,81,96,105,121$, $144,150,164,177$

phallogocentrism, 27

place, $1,4,10,14,36,37,50,54-9$, $67,70,74,79,83,104,127,130$, $134,136,137,140,145,150$, $152,160,165,166,171,176$ imagined, 68 of transit, 159

place and discipline, 132

and 'a room of one's own', 62, $64-5,74,78$

and home, 60-1, 80 and identity, 61

and space, $56-8,80$

and space/bodies, 87

and space/gender, 54

see also gender

positioned rationality, 51

power, 9, 16, 23, 26, 59, 62, 85, 103, 106, 110, 141, 146, 147, 148,

$154,155,158-60,170,177$

affirmative, 2

bio-power, 66, 108, 115

circulation of, 106

effects of, 34, 103

field of, 15

history of, 53

modern, 8

play of, 19,175

sites of, $3,38,120,138$

spatialization of, 53

spirals/networks of power and pleasure, 106, 107

power and desire, 123

and domination, 10, 173

and space/knowledge, 57,58 , 61,66

and subjection, 27, 102

and truth/ethics, 15, 17, 20

and truth/self/writing, 31

as/in discourse, 157

as fields of game, 9

as productive, 17,26

power games, 67, 96, 101, 138, 144

power relations, 9, 10, 13, 19, 20, 25,

$55,66,81,101,103,129,141-2$, 147,173

see also knowledge and resistance prisonhouses, 49, 134, 137

private/public, 1, 143

real-and-imagined geographies, 53, 181

reciprocity, 131, 132, 133, 172,

173,175

relations of forces, 19

repressive hypothesis, 104, 106

resistance, $3,7,24,26,27,34,38-9$, 41, 58-61, 67, 75, 79, 95-6, 98, 101-2, 108, 116, 124, 128, 130, $135,140-1,144,152,157,177-8$ 
reversal, 9

rhizomes, 29, 31, 33

rhythm, 21, 40, 168, 180

scepticism, 8

self, $1,2,3,4,5,7,12,18-20,22-4$, $27,29-39,49-50,52,58,60,64$, 71, 73-5, 78, 81, 94, 101, 103-4, 117-18, 128-30, 132-3, 135-6, $140,142,146,151-4,156-7$, $160,165-7,169,171,174-7$

aesthetics of, 21

care of, 17, 133, 150, 154-6, 169, 171-2, 174

historical self, 37

narratable self, 35

relational self, 171

social self, 145

self-control, 85, 86, 94, 101, 162, 164

self-examination, 94, 155-6, 162, 166

self-practices, 87,167

self-reflection, 92, 94

self-representation, 3, 6, 25-6, 29, $30,31-4,36$

self-writing, $6,26,31,32-4,36-7,39$, $40,46,47,48,53,59,61,83$, 155-6, 162, 174, 175, 177

sex/gender system, 23, 120

sexologists, 105,125

sexuality, 4-5, 18, 22, 103-10,

$114-15,121-3,125,129$,

$132-3,134,160$

construction of, 26

dispositif of, 23

heterosexuality, 26, 119, 126, $129,130,131$

history of, 17, 19, 23, 38, 104-5, 109

peripheral sexualities, 106

scientia sexualis, 104

see also gender and discourses of sexuality

sexuality and gender, 120

and Eros, 152

and love, 121

sexual abuse, 109, 129, 132, 133

sexual attitudes, 124

sexual categories, 108

sexual conduct, 105 sexual desire, $108,115,123,128$

sexual difference, $4,23,27-8,32$, 104, 157

sexual exploitation, 108, 109, 111, 133

sexual fantasies, 128

sexual hypocrisy, 10

sexual identity, 121

sexual intercourse, 118, 124, 154

sexual life, 125

sexual models, 104

sexual morality, 109, 110, 111, 121

sexual puritanism, 105, 109

sexual relationships, 107, 119, 124, 130,131

sexual revolution, 105

sexual roles, 104, 120, 133

sexual subjection, 121

asexual woman, 4, 116, 125

silence, $36,49,103,104,106,107$, $125,129,137,162,164-7$

solitude, $65,92,94,162,165$, 166,170

soul, $15,16,76,85,114,118,120$, $123,124,158,170$

spaces, $1,4,5,46,48,53-83,86-7$, $94,96-8,101,106,113,130,133$,

$141,142,152,156,157,164,176$

conjugal, 104

control of, 98

different, 4, 55, 58, 60, 78, 79

disciplinary, 137, 164

domestic, 60

dominant, 60

enclosed, 52, 59, 66, 82, 137, 142

hegemonic, 79

history of, 53

lived, 55

material, 57, 87

mental, 55

mythical and real, 79

of resistance, 9, 59, 175

of subjectivity, 2

other, $58,60,75,78,80$

paradoxical, 4, 152, 153

perceived

private, $60,61,63,66,67,73,75$, 78,137

public, $66,75,78$ 
spaces - continued

real and imagined, 69, 159

real and metaphorical, 58

reflexive, 155

representational, 57

technologies of, 4, 73, 75, 175

thirdspace, 56, 57, 68

transitional, 39, 50, 73, 74, 80,

150, 157

utopian, 128

see also gender, knowledge, place, power

space and bodies, 87,90

and landscapes, 61

and social relations, 54

space/time, 5, 15, 54, 56, 57, 61, 74,

94, 101, 143, 144, 146, 172

spaces in the margins, 7,58

spatial images, 57, 59

spatial practices, 57

structuralism, 23

subjects, $2,3,5,6,8,9,11,13,15$, $17-19,24,25,27,29-31,33$,

$36-7,39,46,60,71,73-4,92$,

$94,95,101-2,104-5,107,110$, $137,142,156-7,173-4,177$

agentic, 26

autographical, 32, 34

desiring, 103, 123

eccentric, 157

embodied, 2, 28, 151, 178

ethical, 1, 17, 19

female, $1,2,4,22,25,26,33,34$, $35,61,95,135,153,157,173$, $174,175,178$

genealogies of, $15,17,18,104$, 155,174

marginal and submerged, 3

nomadic, 157

objectification of, 16

political, 174

subjectification of, 16,17

technology of, 17

unruly, 34

subjects

as contradicted, 28

as heterogeneous, 6 as heteronomous, 26

as multiple, $6,26,28$

in the process of becoming, 28,178

of autobiography, $6,33-5$

of Enlightenment, 2

of history, 30

see also feminism, gender, knowledge, nomadism

subject positions, 7, 24, 51, 104, 105, 153,156

subjectivities, 6, 2, 18, 20, 23, 26-8, 35, 40, 49, 56-7, 69-71, 80, 102-4, 135-6, $156-7,160$

surveillance, 9, 66-7, 74, 98, 109

technologies of autobiography, 33, $34,35,37$

of gender, 22, 25-6, 29, 35

of power, $15,16,56,104$

of production, 15,16

of resistance, 94, 175, 178

of sign systems, 15,16

of space, $4,73,75,175$

of the self, $1,3,5,14-19$, 28-9, 31, 33, 35-9, 41, 46, $71,73,75,81,85-6,94$, $105,129,133,152,154-6$, $158,162,165-6,172$, $174-5$

telos, 17

topoanalysis, 65,86

topophilia, 64

transgression, 20

truth, 8, 9, 11, 12, 13, 15-16, 17, 19, 20-1, 31, 50, 70, 104, 129, 156, 170,177

effects of, 8, 145

games of, 15, 16

genealogy of multiple truths, 16

politics of, 139, 140

regimes of, 16, 38

truth and asceticism, 19

and experience, 32, 33

and identity, 34

see also knowledge, power 